\title{
Notes
}

\section{A note on references to Fox's Journal}

1 For a comprehensive comparison of Ellwood's first edition and the Spence Manuscript, see Henry J. Cadbury 'The Editio Princeps of Fox's Journal', Journal of the Friends' Historical Society, 53 (1972), 197-218. The question of a manuscript journal as a source for the 1694 printed Journal remains the subject of some uncertainty. Cadbury concludes that the text Fox termed his 'great Jornall' is in fact lost, though similar to the account in the Spence Manuscript and subsequent printed editions; see Henry J. Cadbury (ed.), Annual Catalogue of George Fox's Papers (Philadelphia: Friends Book Store, 1939), 2; see also John L. Nickalls, 'The Journal of George Fox: Some Reasons for and Features of the Forthcoming New Edition', Friends' Quarterly, 6 (1952), 144-51 (146), and H. Larry Ingle, 'George Fox, Historian', Quaker History, 83:1 (1993), 28-35 (33n.8). The character of this lost 'journal' remains uncertain. Penney concludes that the printed Journal 'bears little, if any, evidence of having been preceded by any form of diary, regularly written up, although Ellwood states that Fox "himself kept a Journal"'; see 'Editor's Introduction' in George Fox, The Journal of George Fox, 2 vols, ed. Norman Penney (Cambridge: Cambridge University Press, 1911), I.xxxvii. On a further short autobiographical fragment by Fox, see Geoffrey F. Nuttall, 'A Short Account of Some of G. F.'s Sufferings and Imprisonments', Bulletin of Friends' Historical Association, 39:1 (1950), 27-31.

\section{Introduction}

1 Francis Higginson, A Brief Relation of The Irreligion of the Northern Quakers (London: printed by T. R. for H. R., 1653), A2r-v.

2 Thomas Weld, The Perfect Pharisee under Monkish Holinesse, Opposing the Fundamentall Principles of the Doctrine of the Gospel, and Scripture-Practises of Gospel-Worship manifesting himselfe in the Generation of men called Quakers (Gateside [i.e. Gateshead]: printed by S. B., 1653), 51; William Prynne, The Quakers Unmasked, And clearly 
detected to be but the Spawn of Romish Frogs, Jesuites, and Franciscan Fryers (London: printed for Edward Thomas, 2nd ed., 1655), 1.

3 George Fox, The Journal, ed. Nigel Smith (London: Penguin, 1998), 36.

4 Prynne, The Quakers Unmasked, 5.

5 Fox, Journal, ed. Smith, 86.

6 Higginson, Irreligion of the Northern Quakers, 15, 16; see too George Fox, Saul's Errand to Damascus: With his Packet of Letters from the High-Priests, against the disciples of the Lord (London: printed for Giles Calvert, 1653), 1.

7 Fox, Journal, ed. Smith, 38.

8 Fox, Saul's Errand, 22; original italics

9 George Fox, The Journal of George Fox, ed. John L. Nickalls (Cambridge: Cambridge University Press, 1952), 263.

10 Ibid., 263.

11 Hugh Ormsby-Lennon, 'From Shibboleth to Apocalypse: Quaker Speechways during the Puritan Revolution', in Peter Burke and Roy Porter (eds), Language, Self and Society: A Social History of Language (Cambridge: Polity Press, 1991), $72-112$.

12 The term 'doctrine' suggests something more formally defined than was the case with the theology and religious practices of the early Quakers, whose statements of faith were for the most part informal and responsive, articulated as corrections to the misrepresentations of their beliefs promulgated by their opponents. As Ormsby-Lennon notes, 'the Quakers preferred "prayer" over "doctrine”, spiritual experience over the niceties of theology', with the result that their doctrines 'did not approach any fixity of definition until well after Charles II was restored in 1660'; Ormsby-Lennon, 'From Shibboleth to Apocalypse', 74. Nevertheless, following Frost, among others, I use the word as it best conveys the absolute centrality and unwavering status of the light within as the core of Quaker belief. See J. William Frost, 'The Dry Bones of Quaker Theology', Church History, 39:4 (1970), 503-23.

13 Fox, Journal, ed. Nickalls, 134. For a discussion of Quaker perfectionism, see Chapter 1.

14 For Fox's use of the phrase 'that of God in everyone', see quotation on page 3 above, and 160n.21 below.

15 Frost, 'The Dry Bones of Quaker Theology', 522.

16 The terms 'Publishers of Truth' or 'Public Friends' were used for 'the itinerating Friends with the gift of ministry who spread the Quaker message'; William C. Braithwaite, The Beginnings of Quakerism (Cambridge: Cambridge University Press, 2nd ed., 1955), 26n.1.

17 Edward Burrough, 'A Faithful Testimony Concerning the True Worship of God' (1659), in The Memorable Works of a Son of Thunder and Consolation (s.1.: s.n., 1672), 474-82 (474).

18 Fox, Journal, ed. Nickalls, 144.

19 The phrase references Braithwaite's title, The Second Period of Quakerism, in which that 'second period' is taken as following the Restoration of the monarchy in 1660. Rosemary Moore, in The Light in Their Consciences: The Early Quakers in Britain 
1646-1666 (University Park, PA: Pennsylvania State University Press, 2000), passim and especially 214-28, argues that the shift from an 'early' phase of the movement to a second phase came later, in 1666. For a useful discussion of accommodations made by the movement in the latter part of the seventeenth century, see Adrian Davies, The Quakers in English Society 1655-1725 (Oxford: Clarendon Press, 2000), 216-23.

20 For an overview of the impact of Restoration legislation on Quakers, see ibid., 170-3.

21 Fox issued A Declaration from the Harmless and Innocent People of God, called Quakers, against all plotters and fighters in the world (now known as 'The Peace Testimony') following the Fifth Monarchist uprising of 1661. Here, for the first time, leading Quakers committed themselves to non-violence, for 'the spirit of Christ, which leads us into all Truth, will never move us to fight and war against any man with outward weapons'; Fox, Journal, ed. Nickalls, 398-404 (400). Both the dispute centring on Perrot - the so-called 'hat controversy', concerning whether Friends should always remove their hats in meetings for worship, or whether they should leave the matter to individual conscience - and the activities of Story and Wilkinson, who objected to the formalisation of meetings and growing institutionalisation of the movement, pivoted on the perception that limits were being set on the free leadings of the light. After the Restoration, Fox spent a number of years formalising a more centralised and hierarchical system of meetings, through which the movement organised and governed itself. On the Peace Testimony, see William C. Braithwaite, The Second Period of Quakerism (Cambridge: Cambridge University Press, 2nd ed., 1961), 12-18; H. Larry Ingle, First Among Friends: George Fox and the Creation of Quakerism (Oxford: Oxford University Press, 1994), 172-3, 192-6; Moore, Light in Their Consciences, 180-1. On the movement's internal controversies, see Braithwaite, Second Period of Quakerism, 228-44, 290-323; Kenneth L. Carroll, John Perrot, Early Quaker Schismatic. Journal of the Friends' Historical Society, Supplement 33 (London: Friends', Historical Society, 1971); Ingle, First Among Friends, 197-205, 261-4, Moore, Light in Their Consciences, 193-203. On the changing modes of organisation of the movement, see Braithwaite, Second Period of Quakerism, 251-89; Moore, Light in Their Consciences, 129-41, 180-92, 214-28.

22 Penney's is the only recent edition of the journal to include the complete transcript of the Lancaster trial; Nickalls's edition gives an abbreviated version and Smith's, which comprises only the retrospective narrative portion of the Journal, includes none of this interpolated document.

23 For the epistle to Lampitt, see George Fox, The Journal of George Fox, 2 vols, ed. Norman Penney (Cambridge: Cambridge University Press, 1911), I.87-8; to Sawrey, ibid., I.77; to Cromwell, ibid., I.160-64; to the Long Parliament, ibid., I.79.

24 On the question of the editing of the Journal's accounts of contentious earlier practices, see Henry J. Cadbury, 'The Influence of Fox's Journal', Friends' Quarterly, 15 (1965), 276-81, 295-304; Richard G. Bailey, New Light on George Fox and Early Quakerism: The Making and Unmaking of a God (San Francisco: Mellen Research 
University Press, 1992), xvi-xvii, 77; Thomas N. Corns, “"No Man's Copy”: The Critical Problem of Fox's Journal, in Thomas N. Corns and David Loewenstein (eds), The Emergence of Quaker Writing: Dissenting Literature in Seventeenth-Century England (London: Frank Cass, 1995), 99-111; and pages 83-4 below.

25 See especially Corns, 'No Man's Copy', on this issue.

\section{Chapter 1}

1 Samuel Fisher, Rusticus ad Academicos in Exercitationibus Expostulatoriis, Apologeticis Quatuor. The Rustick's Alarm to the Rabbies (London: printed for Robert Wilson, 1660), B3r.

2 Geoffrey F. Nuttall, The Holy Spirit in Puritan Faith and Experience (Oxford: Basil Blackwell, 1947); Hugh Barbour, The Quakers in Puritan England (New Haven, Yale University Press, 1964); Douglas Gwyn, Apocalypse of the Word: The Life and Message of George Fox (1624-1691) (Richmond, IN: Friends United Press, 1986); Pink Dandelion, The Liturgies of Quakerism (Aldershot: Ashgate, 2005); Pink Dandelion, Douglas Gwyn and Timothy Peat, Heaven on Earth: Quakers and the Second Coming (Kelso: Curlew Productions and Woodbrooke College, 1998); T. L. Underwood, Primitivism, Radicalism, and the Lamb's War: The Baptist-Quaker Conflict in Seventeenth-Century England (Oxford: Oxford University Press, 1997).

3 Barry Reay, The Quakers and the English Revolution (London: Temple Smith, 1985), 3.

4 Francis Higginson, A Brief Relation of The Irreligion of the Northern Quakers (London: printed by T. R. for H. R., 1653), 5-6, 4.

5 Thomas Weld, The Perfect Pharisee under Monkish Holinesse, Opposing the Fundamentall Principles of the Doctrine of the Gospel, and Scripture-Practises of Gospel-Worship manifesting himselfe in the Generation of men called Quakers (Gateside [i.e. Gateshead]: printed by S. B., 1653), 17-18, 19.

6 James Nayler, An Answer to the Booke called The perfect Pharisee under Monkish Holinesse (London: s.n., 1653), 12-13.

7 George Fox, The Great Mistery of the Great Whore Unfolded (London: Tho: Simmons, 1659), 206.

8 Richard Farnworth, The Pure Language of the Spirit of Truth (London: printed for Giles Calvert, 1655), 8; see too George Fox, The Journal, ed. Nigel Smith (London: Penguin, 1998), 87. Fox notes both 'Children of Light' and 'Quakers' as nicknames: ibid., 298. On the early movement's understanding of the 'light', see Nuttall, The Holy Spirit, 42; Gwyn, Apocalypse of the Word, chapter 4; and Rosemary Moore, The Light in Their Consciences: The Early Quakers in Britain 1646-1666 (University Park, PA: Pennsylvania State University Press, 2000), 80-2. Underwood compares Quaker and Baptist understandings of the light: see Underwood, Primitivism, Radicalism, and the Lamb's War, chapters 4 and 7.

9 See too John 1 passim. Fox references John thus: 'the true Light which John bore witness to was the life in Christ the word by which all things was made and created: and it was called the Light in man and woman which was the true Light 
which had enlightened every man that came into the world' (Fox, Journal, ed. Smith, 230). John Story wrote 'this true Light . . . is no other, but even Jesus the everlasting son of God, as the Scriptures testifieth, John. I.9. and John 8.12. Rev. 21, 24. . . This true Light lighteth every man'; John Story, A Short Discovery of certain Truths of God (London: s.n.,1664), 4. In this volume, I quote from the $1611 \mathrm{King}$ James Bible; most sectaries favoured the Geneva Bible, but Friends' allusions to the Bible are usually closer to the former than the latter.

10 Augustine, The Confessions of Saint Augustine, trans. by E. B. Pusey (London: J. M. Dent \& Sons, 1907), 171.

11 Fox, Journal, ed. Smith, 34.

12 On the changes to the Quaker movement after the Restoration, see William C. Braithwaite, The Second Period of Quakerism (Cambridge: Cambridge University Press, 2nd ed., 1961); Hugh Barbour, The Quakers in Puritan England, 234-56; John Punshon, Portrait in Grey: A Short History of the Quakers (London: Quaker Home Service, 1984), chapters 4 and 5; Reay, The Quakers and the English Revolution, chapter 6; Richard G. Bailey, New Light on George Fox and Early Quakerism: The Making and Unmaking of a God (San Francisco: Mellen Research University Press, 1992), chapter 7; Richard G. Bailey, 'Was Seventeenth-Century Quaker Christology Homogeneous?', in Pink Dandelion (ed.), The Creation of Quaker Theory: Insider Perspectives (Aldershot: Ashgate, 2004), 61-82.

13 Fox, Journal, ed. Smith, 34; the Journal returns frequently to the divine origin, character and transformative power of the light, but see in particular ibid., 230, for a definition.

14 Fox, Journal, ed. Smith, 14, my emphasis.

15 James Nayler, Love to the Lost: And a Hand Held Forth to the Helpless, to lead out of the Dark (London: printed for Giles Calvert, 1656), 57; compare Nayler's criticism of those 'wise of the world' who wrongly limit Christ to a place 'above the stars' with the words of Cotton Mather, The Short History of New England (1694), quoted in Nuttall, The Holy Spirit, 135. Fox, Journal, ed. Smith, 15; my emphasis.

16 George Fox, The Journal of George Fox, ed. John L. Nickalls (Cambridge: Cambridge University Press, 1952), 134.

17 Fox, The Great Mistery, 206.

18 Fox, Journal, ed. Nickalls, 134. Rosemary Moore notes that this formulation "comes from the older version of Ephesians 5:30, "For we are members of his body, of his flesh, and of his bones"'; Moore, Light in Their Consciences, 79.

19 Fox, The Great Mistery, 357, 206. For further instances of Fox's designation of Friends as of the 'flesh and bone' of Christ, see Fox, Epistles 99, 155, and 230, in A Collection of Many Select and Christian Epistles, Letters and Testimonies (London: T. Sowle, 1698), 82, 120, 201.

20 Bailey, 'Seventeenth-Century Quaker Christology', 68; Fox, The Great Mistery, 207. In his chapter, Bailey differentiates Fox's Christology from that of other early Quakers. Tarter follows Bailey as a strong proponent of the importance of the idea of 'celestial flesh' to Fox's theology; see Bailey, New Light on George Fox, chapter 4; Michele Lise Tarter, 'Quaking in the Light: The Politics of Quaker Women's Corporeal Prophecy in the Seventeenth-Century Transatlantic World', in Janet 
Moore Lindman and Michele Lise Tarter (eds), A Centre of Wonders: The Body in Early America (Ithaca: Cornell University Press, 2001), 145-62. On Quaker Christology, see too Barbour, The Quakers in Puritan England, 146-9.

21 Fox, Journal, ed. Nickalls, 263. For instances and variations of the phrase 'that of God in everyone' (or close variants) in Fox's writings, see A. N. Brayshaw, The Quakers: Their Story and Message (London: George Allen and Unwin, 3rd ed. 1938), 54n.3, and Arthur Windsor, George Fox Epistles: An Analytical Phrase Index (Gloucester: George Fox Fund, 1992), 252. For opponents' reactions to the indwelling Christ and its implications for their understanding of Fox's theology, see Higginson, Irreligion of the Northern Quakers, 2-5, Weld, Perfect Pharisee, 3-8, and Fox's account of his Lancaster trial in 1652, in Fox, Journal, ed. Nickalls, 133-5. Bailey offers a fascinating analysis of Judge Fell's intervention in Fox's 1652 trial for blasphemy in Lancaster in which he argues that the rebuttal of the charge of claiming equality with God depended on emphasising Fox's claims of unity with God: 'equality' implied two distinct and therefore comparable entities, while 'unity' suggested a single entity, its singularity rendering redundant any notion of comparison, since something cannot be compared with itself. See Bailey, New Light on George Fox, 97-110.

22 On the importance of the indwelling spirit to other Puritan groups, see Nuttall, The Holy Spirit, 150-66, Bailey, New Light on George Fox, 4-6.

23 Martin Mason, The Proud Pharisee Reproved (London, 1655), 36; quoted and discussed by Nigel Smith in 'Hidden Things Brought to Light: Enthusiasm and Quaker Discourse', in Thomas N. Corns and David Loewenstein (eds), The Emergence of Quaker Writing: Dissenting Literature in Seventeenth-Century England (London: Frank Cass, 1995), 57-69 (65).

24 George Fox, Saul's Errand to Damascus: With his Packet of Letters from the HighPriests, against the disciples of the Lord (London: printed for Giles Calvert, 1653), 25; Nayler, Love to the Lost, 57; for a useful discussion of Nayler's conception of the indwelling Christ, see Leo Damrosch,, The Sorrows of the Quaker Jesus: James Nayler and the Puritan Crackdown on the Free Spirit (Cambridge, MA: Harvard University Press, 1996), 92-7.

25 On Quakerism, the press and censorship, see Thomas O'Malley, 'The Press and Quakerism 1653-1659', Journal of the Friends' Historical Society, 54 (1979), 169-84; Thomas O'Malley, “'Defying the Powers and Tempering the Spirit”: A Review of Quaker Control over Their Publications, 1672-1689', Journal of Ecclesiastical History, 33 (1982), 72-88. See too Reay, The Quakers and the English Revolution, 111; Bailey, New Light on George Fox, xvii-xviii, 76-7, 115-20, 137-290; and Thomas N. Corns, “'No Man's Copy”: The Critical Problem of Fox's Journal', in Corns and Loewenstein (eds), The Emergence of Quaker Writing, 99-111. On the excision of accounts of miracles from the published Journal, see Henry J. Cadbury, 'The Influence of Fox's Journal', Friends' Quarterly, 15 (1965), 276-81, 295-304.

26 George Fox, A Journal or Historical Account of the Life, Travels, Sufferings, Christian Experiences and Labour of Love in the Work of the Ministry of that Ancient, Eminent and Faithful Servant of Jesus Christ, George Fox (London: Printed for Thomas Northcott, 1694), 553, 562. 
27 Ibid., 13.

28 John von Rohr, The Covenant of Grace in Puritan Thought (Atlanta, GA: Scholars Press, 1986), 4.

29 Nicholas Tyacke, 'Puritanism, Arminianism and Counter-Revolution', in Margo Todd (ed.), Reformation to Revolution: Politics and Religion in Early Modern England (London: Routledge, 1995), 53-70 (62).

30 Nuttall, The Holy Spirit, 162. On the General Baptists, see Murray Tolmie, The Triumph of the Saints: The Separate Churches of London, 1616-1649 (Cambridge: Cambridge University Press, 1977), 50-84, and J. F. McGregor, 'The Baptists: Fount of All Heresy', in J. F. McGregor and B. Reay (eds), Radical Religion in the English Revolution (Oxford: Oxford University Press, 1984), 23-63.

31 Christopher Hill, The World Turned Upside Down: Radical Ideas During the English Revolution (London: Maurice Temple Smith, 1972; this ed. Harmondsworth: Penguin: 1975), 27.

32 Thomas Collier, A Looking-Glasse for the Quakers (London: printed for Thomas Brewster, 1656), 7.

33 Gerrard Winstanley, 'The New Law of Righteousnes', in The Works of Gerrard Winstanley, ed. George H. Sabine (New York: Russell \& Russell, 1965), 149-244 (165). On Winstanley and Quakerism, see Richard T. Vann, 'From Radicalism to Quakerism: Gerrard Winstanley and Friends', Journal of the Friends' Historical Society, 49 (1959-61), 41-6.

34 Winstanley, 'Truth Lifting Up Its Head Above Scandals' in Works, 97-146 (113, 115).

35 Winstanley, 'Truth Lifting Up Its Head', 127-8. On Winstanley, see Hill, World Turned Upside Down, chapter 7; Hill, The Religion of Gerrard Winstanley (Oxford: Past and Present Society, 1978); David Boulton, Gerrard Winstanley and the Republic of Heaven (Dent: Dales Historical Monographs, 1999); Andrew Bradstock (ed.), Winstanley and the Diggers, 1649-1999 (London: Frank Cass, 2000).

36 In Primitivism, Radicalism, and the Lamb's War, Underwood compares Quaker and Baptist understandings of the light; see especially chapter 7. For notions of the light in other radical groups, see Nigel Smith, Perfection Proclaimed: Language and Literature in English Radical Religion 1640-1660 (Oxford: Clarendon Press, 1989), 66-72, 247-50; Hugh Ormsby-Lennon, 'From Shibboleth to Apocalypse: Quaker Speechways during the Puritan Revolution', in Peter Burke and Roy Porter (eds), Language, Self and Society: A Social History of Language (Cambridge: Polity Press, 1991), 72-112 (78-9, 86-7).

37 Fox, Journal, ed. Nickalls, 134-5; see too Higginson, Irreligion of the Northern Quakers, 2-3, and Fox, Saul's Errand, 5-6, 10-11.

38 Higginson, Irreligion of the Northern Quakers, 3.

39 Quoted in Underwood, Primitivism, Radicalism, and the Lamb's War, 36.

40 For the fullest account and analysis of this episode, see Damrosch, Sorrows of the Quaker Jesus, passim, and especially 146-62, 222-9. See too William C. Braithwaite, The Beginnings of Quakerism (Cambridge: Cambridge University Press, 2nd ed., 1955), 241-78; Moore, Light in Their Consciences, 35-48.

41 Damrosch, Sorrows of the Quaker Jesus, 73. 
42 The doctrine of perfectibility had also been found among members of the Family of Love and the Grindletonians; see Hill, World Turned Upside Down, 81-5, 166; Damrosch, Sorrows of the Quaker Jesus, 93-4.

43 Fox, Journal, ed. Smith, 27, 27-8.

44 Fox, Saul's Errand, 12; original emphasis.

45 Edward Burrough, 'A Declaration to all the World of our Faith' (1658), in The Memorable Works of a Son of Thunder and Consolation (s.1.: s.n., 1672), 439-43 (441); Moore, Light in Their Consciences, 86; Nayler, 'Concerning Perfection', in Love to the Lost, 21. It is worth noting too that Fox's statement regarding perfection is taken from the early pages of the Journal, and is thus available only in Ellwood's 1694 edition as approved by the Second Day Morning Meeting, since the early pages of the manuscript journal are lost. The perfectionist claims, therefore, were allowed to stand, just as were the claims regarding the corporeal indwelling by Christ. Note too John Story's statement, expressed as 'Doctrine', regarding perfection in 1660: 'we say that the perfection of the Saints was and is attainable in and through Christ, even while they were and are upon the Earth, or else the work for which the true Ministry was given, had been void'; John Story, Babilons Defence Broken down, and one of Antichrists Warriours Defeated: In an Answer to a Scandalous Pamphlet, Intituled, The Quaker-Jesuit: Or, Popery in Quakerism (London: printed for Robert Wilson, 1660), 8. See too Weld, Perfect Pharisee, 14-17.

46 On perfection, see L. Hugh Doncaster, 'Early Quaker Thought on "That State in which Adam was before he Fell", Journal of the Friends' Historical Society, 41:1 (1949), 13-24; Hugh Barbour, The Quakers in Puritan England, 149-52; and J. William Frost, 'The Dry Bones of Quaker Theology', Church History, 39:4 (1970), 503-23 (516-17).

47 Blair Worden, 'Providence and Politics in Cromwellian England', Past and Present, 109:1 (1985), 55-99 (55).

48 Fox, Journal, ed. Smith, 11-12.

49 Ibid., 16-17.

50 Fox, Journal, ed. Smith, 16. The 'discerning spirit' is a reference to 1 Corinthians 12.10: 'To another the working of miracles; to another prophecy; to another discerning of spirits; to another divers kinds of tongues; to another the interpretation of tongues'. The subsequent two verses are telling with regard to the argument I go on to make about the relationship between 'discerning' and 'unity': 'But all these worketh that one and the selfsame Spirit, dividing to every man severally as he will. For as the body is one, and hath many members, and all the members of that one body, being many, are one body: so also is Christ.'

51 Richard Gilpin, The Agreement of the Associated Ministers \& Churches of the Counties of Cumberland, and Westmerland (London: printed by T. L. for Simon Waterson, 1656), 57. See too Benjamin Nightingale, The Ejected of 1662 in Cumberland and Westmorland: Their Predecessors and Successors, 2 vols (Manchester: Manchester University Press, 1911), I.101.

52 Fox, Journal, ed. Smith, 20. See 156n.16 for note on 'Publishers of Truth'.

53 Ibid., 128, 129.

54 Also Revelation 12.17: 'And the dragon was wroth with the woman, and went to 
make war with the remnant of her seed, which keep the commandments of God, and have the testimony of Jesus Christ'. On 'the Seed', see T. Joseph Pickvance, 'George Fox's Use of the Word “Seed”, Journal of the Friends' Historical Society, 41 (1949), 25-8; Nuttall, The Holy Spirit, 157-9. Douglas Gwyn, Apocalypse of the Word: The Life and Message of George Fox (1624-1691) (Richmond, IN: Friends United Press, 1986), 68-71; Moore, Light in Their Consciences, 82-3.

55 Priscilla Cotton and Mary Cole, 'To the Priests and People of England' (London: for Giles Calvert, 1655); reprinted as an appendix to Hilary Hinds, God's Englishwomen: Seventeenth-Century Radical Sectarian Writing and Feminist Criticism (Manchester: Manchester University Press, 1996), 222-6 (222).

56 Nayler, An Answer to the Booke called The perfect Pharisee, 29.

57 Fox, Journal, ed. Smith, 90.

58 Fox, Journal, ed. Nickalls, 263.

59 On the implications of early Friends' notions of unity, see Moore, Light in Their Consciences, 78-9.

60 Fox, Journal, ed. Smith, 28. See ibid., 82, on the relation between the Bible and individual apprehension of the truth.

61 Quoted by Jackson I. Cope, 'Seventeenth-Century Quaker Style', PMLA, 71 (1956), 725-54 (731).

62 Fox, Journal, ed. Nickalls, 228.

63 'Extracts from William Penn's Preface to the Original Edition of George Fox's Journal, 1694', in Fox, Journal, ed. Nickalls, xlvi.

64 Fox, Journal, ed. Nickalls, 282. Indeed, when Friends exhibited 'leadings' that contradicted those of the principal Friends, these tended to produce deep schisms (such as the Nayler episode of 1656, the Hat Controversy precipitated by John Perrot in the early 1660s, and the Wilkinson-Story dispute of the mid-1670s), for one was either in the light or out of it; there was no half-way house. On these disputes, see Braithwaite, Beginnings of Quakerism and Second Period of Quakerism.

65 This impetus found its most famous extrapolation in the so-called Peace Testimony of 1660, in the affirmation that 'all people, out of all different judgements and professions may be brought into love and unity with God, and one with another, and that they may all come to witness the prophet's words who said, "Nation shall not lift up sword against nation, neither shall they learn war any more."” Fox, Journal, ed. Nickalls, 400.

66 Farnworth, The Pure Language, 7.

67 William Prynne, The Quakers Unmasked, And clearly detected to be but the Spawn of Romish Frogs, Jesuites, and Franciscan Fryers (London: printed for Edward Thomas, 2nd ed., 1655). Prynne was not alone among opponents of Quakerism to accuse them of links with Roman Catholicism, an accusation strengthened by their affirmation of a degree of agency in matters of salvation. Higginson wrote that 'Papists are open Idolaters, and the Propagators of your Superstitions are more horrid Blasphemers: most of your Errours may throw down the Gauntlet to the worst of theirs, besides many that you hold in common with them' (Higginson, Irreligion of the Northern Quakers, a2v, original emphasis); Nayler complained that in The Perfect Pharisee Thomas Weld had misrepresented Friends and their deeds, which 'they doe in obedience to God, 
under the name of Monkish Holinese, Fryars, Pharisees, or any thing that in their subtilty they conceive will make them most odious to people' (Nayler, An Answer to the Booke called The perfect Pharisee, 3, original emphasis); and Richard Gilpin urged people to 'Observe what a favourable aspect all their opinions have to Popery' (Gilpin, The Agreement of the Associated Ministers \& Churches of the Counties of Cumberland, and Westmerland, 1656), 57). See too William Brownsword, The Quaker Jesuite, or Popery in Quakerism (London: printed by J. M., 1660), and, for discussion of this criticism, Phyllis Mack, Visionary Women: Ecstatic Prophecy in Seventeenth-Century England (Berkeley: University of California Press, 1992), 249-50, and Moore, Light in Their Consciences, 92, 265n.15.

68 Fisher, Rusticus ad Academicos, B3r; his emphasis. On Fisher, see Braithwaite, Beginnings of Quakerism, 288-94, Hill, World Turned Upside Down, 259-68; Smith, Perfection Proclaimed, 296-9; Nicholas McDowell, The English Radical Imagination: Culture, Religion, and Revolution, 1630-1660 (Oxford: Clarendon Press, 2003), 137-82.

69 Fisher, Rusticus ad Academicos, B3r; his emphasis.

70 Sarah Jones, This is Lights Appearance in the Truth (s.l. [London?]: s.n., [1650]), 2. Fox, Journal, ed. Nickalls, 347-8.

71 Fisher, Rusticus ad Academicos, B3r-v.

72 Burrough, 'A Declaration', 441.

73 Fisher, Rusticus ad Academicos, B3v.

74 Jones, This is Lights Appearance, 1.

75 Later Friends were also urged to 'sink down' into the light: when 'temptations and troubles appear', Fox wrote, people should 'sink down in that which is pure, and all will be hushed, and fly away'; and Charles Marshall also exhorted Friends to 'sink down into the pure Stilness'. George Fox, Epistle 10, 'To Friends, 1652', in Hugh Barbour and Arthur O. Roberts (eds), Early Quaker Writings, 1650-1700 (Grand Rapids, MI: Eerdmans, 1973), 487; Charles Marshall, An Epistle to Friends coming forth in the Beginning of a Testimony and of the Snares of the Enemy Therein (London?: s.n., 1730?), 4.

76 Fox, Journal, ed. Smith, 212, 222.

77 Norman Penney (ed.), The First Publishers of Truth: Being Early Records (Now First Printed) of the Introduction of Quakerism into the Counties of England and Wales. Supplement to Journal of the Friends' Historical Society, 1-5 (London: Headley Brothers, 1907), 241-2.

78 Fisher, Rusticus ad Academicos, B3r.

\section{Chapter 2}

1 Francis Higginson had been instrumental in the arrest of James Nayler and Francis Howgill in Kirkby Stephen in November 1652, which resulted in their trial for blasphemy in Appleby in January 1653; see Kate Peters, Print Culture and the Early Quakers (Cambridge: Cambridge University Press, 2005), 185, and 181-90. Regarding his first-hand experience of Quakers, Higginson wrote, 'I once heard 
Naylor speak a while my selfe; I have enquired of divers that have been the Auditors of others of them, I have read very many of their Epistles and Papers that are common in the Country'; Francis Higginson, A Brief Relation of The Irreligion of the Northern Quakers (London: printed by T. R. for H. R., 1653), 14. See George Fox, Saul's Errand to Damascus: With his Packet of Letters from the High-Priests, against the disciples of the Lord (London: printed for Giles Calvert, 1653), 29-34, and Higginson, Irreligion of the Northern Quakers, 69-73, for accounts of Nayler's appearance in court in Appleby, including the exchange between Nayler and Higginson.

2 Higginson, Irreligion of the Northern Quakers, 11, 12.

3 Ibid., 11. For an analysis of Quaker gesture and deportment in relation to codes of civility, see Adrian Davies, The Quakers in English Society 1655-1725 (Oxford: Clarendon Press, 2000), 57-63.

4 Higginson, Irreligion of the Northern Quakers, 15.

5 Ibid., 16.

6 For examples of accusations of witchcraft made against and by Fox and other Friends, see George Fox, The Journal, ed. Nigel Smith (London: Penguin, 1998), 110, 117, 120, 268; and on links made between Roman Catholicism and Quakerism, see 163n.67.

7 For a discussion that also analyses the disturbance caused by early Quakerism in relation to Friends' rhetoric, see Meiling Hazelton, “Mony Choaks": The Quaker Critique of the Seventeenth-Century Public Sphere', Modern Philology, 98:2 (2000), 251-70. She argues that opponents' unease and opposition can be traced to the Quaker excoriation of the clergy's commodification of scripture and their counter-advocacy of a 'communism of language' (Hazelton, 'Mony Choaks', 258).

8 The sudden expansion of the movement in 1652-53, as Fox travelled through Lancashire, Westmorland and Cumberland, has led scholars to dub this area 'the Quaker Galilee'; see for example Hugh Barbour, The Quakers in Puritan England (New Haven, Yale University Press, 1964), 42; Michael Watts, The Dissenters: From the Reformation to the French Revolution (Oxford: Oxford University Press, 1978), 285; Hugh Ormsby-Lennon, 'From Shibboleth to Apocalypse: Quaker Speechways during the Puritan Revolution', in Peter Burke and Roy Porter (eds), Language, Self and Society: A Social History of Language (Cambridge: Polity Press, 1991), 72-112 (72).

9 Higginson, Irreligion of the Northern Quakers, 14-15.

10 Ibid., 34.

11 See too for example Anon., The Querers and Quakers Cause at the Second Hearing (London: printed by I. G. for Nath: Brooke, 1653).

12 Douglas Gwyn, Apocalypse of the Word: The Life and Message of George Fox (16241691) (Richmond, IN: Friends United Press, 1986), 67. 'Convincement' also retained the sense of 'persuasion' at this time (as in Areopagitica, when Milton writes of those who, through reading, are 'trying all things, assenting to the force of reason and convincement'; John Milton, Areopagitica, in Prose Writings (London: J. M. Dent, 1958), 177), but, as I go on to discuss in this chapter, 'persuasion' is a complex issue in the context of Quaker ideas of convincement and the indwelling light. 
13 Norman Penney (ed.), The First Publishers of Truth: Being Early Records (Now First Printed) of the Introduction of Quakerism into the Counties of England and Wales. Supplement to Journal of the Friends' Historical Society, 1-5 (London: Headley Brothers, 1907), 296, 286; John Story, Babilons Defence Broken down, and one of Antichrists Warriours Defeated: In an Answer to a Scandalous Pamphlet, Intituled, The Quaker-Jesuit: Or, Popery in Quakerism (London: printed for Robert Wilson, 1660), 8. Barbour offers a full account of Friends' records of the protracted and painful process of convincement; Barbour, The Quakers in Puritan England, 94-126.

14 Fox, Saul's Errand to Damascus, 5; see too Nayler in ibid., 33.

15 Penney, First Publishers of Truth, 43.

16 Richard Bauman, Let Your Words Be Few: Symbolism of Speaking and Silence among Seventeenth-Century Quakers (Cambridge: Cambridge University Press, 1983), 81, my italics.

17 Penney, First Publishers of Truth, 290.

18 Fox, Journal, ed. Smith, 17.

19 Penney, First Publishers of Truth, 290, 297.

20 Gwyn, Apocalypse of the Word, 67; his emphasis. On convincement, see too ibid., 133-5, Richard T. Vann, The Social Development of English Quakerism 1655-1755 (Cambridge, MA: Harvard University Press, 1969), 1-46; Bauman, Let Your Words Be Few, 63-83.

21 Cope and Vann note Quaker resistance to the notion of rhetoric in relation to their own practice; Bauman, Ormsby-Lennon, Hawes, McDowell and Graves, however, all use the term in relation to Quaker discourse. For scholars who use the term 'rhetoric' in their analysis, see Jackson I. Cope, 'SeventeenthCentury Quaker Style', PMLA, 71 (1956), 725-54 (732-3); Vann, Social Development of English Quakerism, 2; Bauman, Let Your Words Be Few, 76-8; Ormsby-Lennon, 'From Shibboleth to Apocalypse', 96; Clement Hawes, Mania and Literary Style: The Rhetoric of Enthusiasm from the Ranters to Christopher Smart (Cambridge: Cambridge University Press, 1996), 18-19; Nicholas McDowell, The English Radical Imagination: Culture, Religion, and Revolution, 1630-1660 (Oxford: Clarendon Press, 2003), 164. Michael P. Graves, Preaching the Inward Light: Early Quaker Rhetoric (Waco, TX: Baylor University Press, 2009), offers an extremely comprehensive and systematic contextual engagement of the notion of a 'Quaker rhetoric' in relation to an analysis of Quaker sermons from the latter part of the seventeenth century.

22 OED 1a.

23 John Smith, The Mysterie of Rhetorique Unvail'd (London: printed by E. Cotes for George Eversden, 1657), 1; John Prideaux, Sacred Eloquence: Or, the Art of Rhetorick, as it is layd down in Scripture (London: printed by W. Wilson for George Sawbridge, 1659), 58.

24 Vann, Social Development of English Quakerism, 9-10.

25 Penney, First Publishers of Truth, 296.

26 Kenneth Burke, A Rhetoric of Motives (1950; this ed. republished with A Grammar of Motives, Cleveland and New York: Meridian Books, 1962), 547.

27 Ibid., 544-5. 
28 Ibid., 570.

29 Ibid., 582.

30 Ibid.

31 See Cope, 'Seventeenth-Century Quaker Style'; Ormbsy-Lennon, 'From Shibboleth to Apocalypse'; Bauman, Let Your Words Be Few; and Graves, Preaching the Inward Light, 157-224.

32 Burke, Rhetoric of Motives, 551-2.

33 For Friends, a general distrust of human language as a faulty aspect of fallen creation combined with an acute distrust of the ways and words of 'hireling priests', the Church of England clergy supported by tithes, so that the only word of worth was the one uttered by the inward voice of the Lord. Consequently, Vann notes, when Quakers 'put pen to paper in the effort to reach the witness of God within other men, they shunned the artifices of rhetoric and syllogism'; Vann, Social Development of English Quakerism, 2.

34 Penney, First Publishers of Truth, 297.

35 Fox, Journal, ed. Smith, 122.

36 Dorothy Waugh, 'A Relation concerning Dorothy Waughs cruell usage by the Mayor of Carlile', in Anon., The Lambs Defence Against Lyes (London: printed for Giles Calvert, 1656); reprinted as an appendix to Hilary Hinds, God's Englishwomen: Seventeenth-Century Radical Sectarian Writing and Feminist Criticism (Manchester: Manchester University Press, 1996), 227-8 (227).

37 Ibid.

38 On the use of the bridle, see David E. Underdown, 'The Taming of the Scold: The Enforcement of Patriarchal Authority in Early Modern England', in A. J. Fletcher and J. Stevenson (eds), Order and Disorder in Early Modern England (Cambridge: Cambridge University Press. 1985), 116-36; Lynda E. Boose, 'Scolding Brides and Bridling Scolds: Taming the Woman's Unruly Member', Shakespeare Quarterly, 42:2 (1991), 179-213; Martin Ingram, “'Scolding Women cucked or washed”: A Crisis in Gender Relations in Early Modern England', in Jenny Kermode and Garthine Walker (eds), Women, Crime, and the Courts in Early Modern England (Chapel Hill: University of North Carolina Press, 1994), 48-80.

39 N. H. Keeble, “"Take away preaching, and take away salvation”: Hugh Latimer, Protestantism, and Prose Style', in Neil Rhodes (ed.), English Renaissance Prose: History, Language, and Politics (Tempe, AZ: Medieval and Renaissance Texts and Studies, vol. 164, 1997), 57-74 (57).

40 Latimer, quoted in ibid., 61.

41 Bryan Crockett, The Play of Paradox: Stage and Sermon in Renaissance England (Philadelphia: University of Pennsylvania Press, 1995), 6.

42 Debora Kuller Shuger, 'Sacred Rhetoric in the Renaissance', in Heinrich F. Plett (ed.), Renaissance Rhetoric (Berlin, New York: Walter de Gruyter, 1993), 121-42 (123).

43 Ibid., 125.

44 The definitions of amplification and hypotyposis are from the OED. Shuger, 'Sacred Rhetoric', 127.

45 Smith, The Mysterie of Rhetorique, 112; my emphasis. 
46 Shuger, 'Sacred Rhetoric', 127. It was authors such as Keckermann and Franco Burgersdijck 'who were most widely read and who represented scholasticism to most people in the seventeenth and eighteenth centuries'; John A. Trentman, 'Scholasticism in the Seventeenth Century', in Norman Kretzmann, Anthony Kenny, Jan Pinborg and Eleonore Stump (eds), The Cambridge History of Later Medieval Philosophy (Cambridge: Cambridge University Press, 1982), 818-37 (835).

47 Shuger, 'Sacred Rhetoric', 126.

48 Bauman, Let Your Words Be Few, 73. Bauman notes that Michael P. Graves found only ten extant Quaker sermons recorded before 1687, all by Fox; ibid., 74.

49 Fox, Journal, ed. Smith, 86.

50 George Fox, The Journal of George Fox, 2 vols, ed. Norman Penney (Cambridge: Cambridge University Press, 1911), I.145; Penney's brackets. I refer to this edition here because, while the epistle constitutes part of the Journal, Smith omits all the epistles from his edition, and Nickalls includes only a much shortened version in his (on 174-6). The passage thus cited also has the advantage of giving an indication of the style and rhythm of the unedited text.

51 On the incantatory quality of early Quaker discourse, see Cope, SeventeenthCentury Quaker Style, 733, and Bauman, Let Your Words Be Few, 76.

52 Cope, 'Seventeenth-Century Quaker Style', 730-7.

53 Fox, Journal, ed. Penney, I.79.

54 Margret Killin and Barbara Patison, A Warning from the Lord to the Teachers \& People of Plimouth (London: printed for Giles Calvert, 1655), 2.

55 Latimer, quoted by Keeble, 'Take away preaching', 61.

56 Shuger, 'Sacred Rhetoric', 126, 133.

57 Prideaux, Sacred Eloquence, 77.

58 Joseph Glanvill, An Essay Concerning Preaching: Written for the Direction of A Young Divine; and Useful also for the People, in order to Profitable Hearing (London: printed by A. C. for H. Brome, 1678), 54.

59 Shuger, 'Sacred Rhetoric', 131.

60 On Quaker plain style, see Frederick B. Tolles, “'Of the Best Sort but Plain”: The Quaker Esthetic', American Quarterly 11:4 (1959), 484-502 (487), and Adrian Davies, The Quakers in English Society 1655-1725 (Oxford: Clarendon Press, 2000), 44-8; on Quaker linguistic 'plain style', see Ormsby-Lennon, 'From Shibboleth to Apocalypse', passim.

61 Shuger, 'Sacred Rhetoric', 135.

62 Ibid.

63 Cicero considered actio (delivery) to be 'the dominant factor in oratory', and both he and Quintilian emphasised the performative dimensions of oratorical delivery. See Cicero, De Oratore, 2 vols (London: William Heinemann, 1942), III.56.213-61.228; II.169-83; Quintilian, Instituto Oratoria, XI.3, in Quintilian, The Orator's Education, Books 11-12, ed. and trans. Donald A. Russell (Cambridge, MA: Harvard University Press, 2001), 85-183. For an overview of the debate about oratory and acting, see Neil Rhodes, The Power of Eloquence and English Renaissance Literature (Hemel Hempstead: Harvester Wheatsheaf, 1992), 12-19. Many thanks to Alison Thorne for providing these references, and for clarifying 
the correspondence between classical and sacred rhetoric on this issue. Crockett, in The Play of Paradox, explores the congruence between Protestantism and theatre.

64 Shuger 'Sacred Rhetoric', 137.

65 William Perkins, The Arte of Prophecying: Or A Treatise Concerning the Sacred and Onely true manner and methode of Preaching (London: by Felix Kyngston for E. E., 1607), 143-4.

66 William Greenhill, Sermons of Christ (London: R. I. for Livewell Chapman, 1656), A $4 \mathrm{v}$.

67 Fox, Journal, ed. Smith, 122.

68 Prideaux, Sacred Eloquence, 14.

69 Smith, The Mysterie of Rhetoric, 2, 7.

70 Waugh, 'A Relation concerning Dorothy Waughs cruell usage', 227. In the Bible, Egypt is a symbol of captivity, repression and worldliness.

71 Joseph Besse, A Collection of the Sufferings of the People called Quakers, 2 vols (London: printed and sold by Luke Hinde, 1753), I.519.

72 Fox, Journal, ed. Smith, 122; Waugh, 'A Relation concerning Dorothy Waughs cruell usage', 227.

73 Ibid., 227.

74 George Fox, The Journal of George Fox, ed. John L. Nickalls (Cambridge: Cambridge University Press, 1952), 134-5.

75 Fox, Saul's Errand to Damascus, 8.

76 Norman Penney, 'Going Naked a Sign', in Penney, First Publishers of Truth, 364-9 (364). See Kenneth L. Carroll, 'Early Quakers and "going naked as a sign”, Quaker History, 67:2 (1978), 69-87, and Bauman, Let Your Words Be Few, 84-94, for delineation and discussion of nakedness and other kinds of Quaker 'sign'.

77 George Fox, 'The Short Journal', in The Short Journal and Itinerary Journals of George Fox, ed. Norman Penney (Cambridge: Cambridge University Press, 1925), 1-72 (21).

78 Fox, Journal, ed. Smith, 85.

79 Penney, First Publishers of Truth, 259.

80 Fox, Journal, ed. Penney, I.89; ' $\mathrm{y}^{\mathrm{t}}$ ' and ' $\mathrm{y}$ ' ' are the form of 'that' and 'them' generally used in the Spence Manuscript, the copy-text for Penny's edition of the Journal.

81 Penney, First Publishers of Truth, 213. Fox wrote that Simpson 'went three years Naked and in Sackcloth, in the days of Oliver and his Parliament as a Sign to them, and to the Priests shewing how God would strip them of their power, and that they should be as Naked as he was, and should be stript of their Benefices . . . And moreover he was made oftentimes to colour his face black, and so black they should be and appear so to people, for all their great profession; and so it came to pass. And then when it came to pass he was made to put on his clothes again.' Quoted by Carroll, 'Early Quakers and “going naked as a sign”, 78.

82 Cited and discussed by ibid., 79, and Bauman, Let Your Words Be Few, 89.

83 Higginson, Irreligion of the Northern Quakers, 29-30.

84 The performances of other kinds of sign, such as Thomas Aldam's rending of his hat in front of Oliver Cromwell, were subject to similarly diverse interpretations by Friends themselves; see Bauman, Let Your Words Be Few, 86-7. 
85 Ibid., 92.

86 Nayler cited by Braithwaite, Beginnings of Quakerism, 256.

87 George Fox, John Stubs and Benjamin Furley, 'Introduction', in A Battle-Door for Teachers \& Professors to Learn Singular and Plural (London: printed for Robert Wilson, 1660), A2v.

88 On the relative importance of speech and silence in early Quakerism, see Bauman, Let Your Words Be Few, especially chapters 2 and 8. See too Pink Dandelion, The Liturgies of Quakerism (Aldershot: Ashgate, 2005), 21-33, and Ormsby Lennon, 'From Shibboleth to Apocalypse', 93-4.

89 The phrase 'Let your lives speak' is to be found on the plaque on Fox's Pulpit at Firbank Fell, Sedbergh. Despite the phrase frequently being attributed to Fox, I have been unable to identify a precise source for it. The closest I have found are cited here: the phrase from the Journal can be found in Fox, Journal, ed. Smith, 129, and see too Fox, Journal, ed. Nickalls, 263: 'that your carriage and life may preach among all sorts of people'. The words from the Epistles are taken from Epistle 200 in George Fox, The Works of George Fox (Philadelphia: Marcus T. C. Gould, 1831), 7.191-8 (194).

90 'Alice Cobb's Testimony concerning her Mother Alice Curwen', in Alice Curwen, A Relation of the Labour, Travail and Suffering of that faithful Servant of the Lord Alice Curwen (London: s.n., 1680), n.pag.

91 Waugh, 'A Relation concerning Dorothy Waughs cruell usage', 227.

92 For fuller discussion of this point with regard to the spatialised politics of sectarian discourse in the 1650s, see Hilary Hinds, 'Sectarian Spaces: The Politics of Place and Gender in Seventeenth-Century Prophetic Writing', Literature and History, 13:2 (2004), 1-25.

93 The phrase is taken from Richard G. Bailey, New Light on George Fox and Early Quakerism: The Making and Unmaking of a God (San Francisco: Mellen Research University Press, 1992), but is also used by Michele Lise Tarter in her 'Quaking in the Light: The Politics of Quaker Women's Corporeal Prophecy in the Seventeenth-Century Transatlantic World', in Janet Moore Lindman and Michele Lise Tarter (eds), A Centre of Wonders: The Body in Early America (Ithaca: Cornell University Press, 2001), 145-62.

94 Fox, Journal, ed. Smith, 86.

\section{Chapter 3}

1 Mark Breitenberg, Anxious Masculinity in Early Modern England (Cambridge: Cambridge University Press, 1996), 2.

2 John Stachniewski and Anita Pacheco, 'Introduction', in John Bunyan, Grace Abounding with Other Spiritual Autobiographies, ed. John Stachniewski and Anita Pacheco (Oxford: Oxford University Press, 1998), xiv.

3 John R. Knott, Discourses of Martyrdom in English Literature, 1563-1694 (Cambridge: Cambridge University Press, 1993), 246.

4 Oliver Cromwell, Oliver Cromwell's Letters and Speeches, with Elucidations by 
Thomas Carlyle, vol. 3 (London: Dent, 1907), 341; H. Larry Ingle, First Among Friends: George Fox and the Creation of Quakerism (Oxford: Oxford University Press, 1994), 37; H. Larry Ingle, 'Unravelling George Fox: The Real Person', in Michael Mullett (ed.), New Light on George Fox 1624-1691 (York: The Ebor Press, 1994), 38.

5 William C. Braithwaite, The Beginnings of Quakerism (Cambridge: Cambridge University Press, 2nd ed., 1955), 39; Braithwaite, The Second Period of Quakerism (Cambridge: Cambridge University Press, 2nd ed., 1961), 438, 439.

6 T. Edmund Harvey, 'Introduction', in The Journal of George Fox, ed. Norman Penney, 2 vols (Cambridge: Cambridge University Press, 1911), I.xxix. Cope and Bartell also note the confidence of the tone of the Journal; see Jackson I. Cope, 'Seventeenth-Century Quaker Style', PMLA, 71 (1956), 725-54 (726); Shirley Miller Bartell, 'Uncertainty in Bunyan versus Assurance in Fox', Quaker History, 58 (1969), 93-103 (101). Doncaster makes a similar point when he notes that 'it was a fact that they did know an amazing release from the burden and bondage of sin'; L. Hugh Doncaster, 'Early Quaker Thought on "That State in which Adam was before he Fell"', Journal of the Friends' Historical Society, 41:1 (1949), 13-24 (21).

7 Cope calls this 'perhaps the most insistent single phrase in Fox's Journal', and Bartell notes it as 'the characteristic response he made to almost every situation'. Cope, 'Seventeenth-Century Quaker Style', 730; Bartell, 'Uncertainty in Bunyan versus Assurance in Fox', 101.

8 John Stachniewski, The Persecutory Imagination: English Puritanism and the Literature of Religious Despair (Oxford: Clarendon Press, 1991).

9 Naomi Winter, "'Out of the Paths and Steps of Solid Men" - Masculinities in George Fox's Journal', Literature and Theology, 14:2 (2000), 145-59 (149).

10 Knott, Discourses of Martyrdom, 246.

11 See for example Lynn Enterline, The Tears of Narcissus: Melancholia and Masculinity in Early Modern Writing (Stanford, CA: Stanford University Press, 1995), a study of the 'literary melancholia' of the Renaissance, and in particular its 'presumption that the melancholic subject is male', in which she argues that 'melancholia disturbs the presumed sexual "identity" of self-representing masculine subjects' $(8,7,9)$. On the threat to masculinity posed by early modern ideas about gender indeterminacy, see Stephen Orgel, Impersonations: The Performance of Gender in Shakespeare's England (Cambridge: Cambridge University Press, 1996), especially 25-9, 123-5.

12 Breitenberg, Anxious Masculinity, 2.

13 Ibid., 5.

14 Stephen Greenblatt, Renaissance Self-Fashioning from More to Shakespeare (Chicago: University of Chicago Press, 1980), 141. For discussion of the interconnections between Calvinism and sexuality in the formation of subjectivities, see Greenblatt, Renaissance Self-Fashioning, 122-6, 241-51. The line 'I love an other and thus I hate myself' is from Sir Thomas Wyatt's Sonnet XXVI, 'I find no peace, and all my war is done', in Thomas Wyatt, Collected Poems, ed. Joost Daalder (London: Oxford University Press, 1975), 24.

15 Breitenberg, Anxious Masculinity, 4. 
16 Roger Smith, 'Self-Reflection and the Self', in Roy Porter (ed.), Rewriting the Self: Histories from the Renaissance to the Present (London: Routledge, 1997), 54.

17 Gary Waller, 'The Rewriting of Petrarch: Sidney and the Languages of SixteenthCentury Poetry', in Gary Waller and Michael D. Moore (eds), Sir Philip Sidney and the Interpretation of Renaissance Culture (London: Croom Helm, 1984), 69-83 (77).

18 Article XVII of 'Articles of Religion' (39 Articles) prepared first under Edward VI, confirmed under Elizabeth, read in part: 'Predestination to life is the everlasting purpose of God, whereby (before the foundations of the world were laid) he hath constantly decreed by his counsel secret to us, to deliver from curse and damnation those whom he hath chosen in Christ out of mankind, and to bring them by Christ to everlasting salvation, as vessels made to honour'; quoted in John von Rohr, The Covenant of Grace in Puritan Thought (Atlanta, GA: Scholars Press, 1986), 113.

19 Bunyan, Grace Abounding, 20.

20 Regarding Astrophil and Stella, see Waller, 'The Rewriting of Petrarch', and Marion Campbell, 'Unending Desire: Sidney's Reinvention of Petrarchan Form in Astrophil and Stella', in Waller and Moore (eds), Sir Philip Sidney, 84-94.

21 Bunyan, Grace Abounding, 94.

22 For a comparison of the characteristic affective states of Fox and Bunyan as produced in their autobiographical writings, see Bartell, 'Uncertainty in Bunyan versus Assurance in Fox'. Hugh Barbour compares Fox's and Bunyan's experience of conversion in 'The "Openings" of Fox and Bunyan', in Mullett (ed.), New Light on George Fox, 129-43. For a comparison of Puritan spiritual autobiographies (including Bunyan's) with Quaker modes of self-representation, see Cope, 'Seventeenth-Century Quaker Style'.

23 Richard Norwood, 'Confessions' (written 1639-40), in Bunyan, Grace Abounding, 153.

24 The term 'subjectification' derives from Foucault, and refers to the 'way a human being turns him- or herself into a subject', indicating a concern with 'those techniques through which the person initiates an active self-formation. . . These operations characteristically entail a process of self-understanding but one which is mediated by an external authority figure'; Paul Rabinow, 'Introduction', in Paul Rabinow (ed.), The Foucault Reader (London: Penguin, 1991), 11. Stachniewski adopts the term because it 'points to the collaboration of internal with external agencies of control through the medium of discourse' (Stachniewski, The Persecutory Imagination, 6). He elaborates the point thus: “"There are two meanings of the word subject," says Foucault: "subject to someone else by control and dependence, and tied to his own identity by a conscience or self-knowledge. Both meanings suggest a form of power which subjugates and makes subject to." The discourse of Calvinism was the power source into which spiritual autobiographers were plugged; and its disciplinary shocks were administered by the agency of both authority figures and the mental processes they had trained to deputize for them' (ibid., 85).

25 Hannah Allen, A Narrative of God's Gracious Dealings With that Choice Christian Mrs. Hannah Allen (London: printed for John Wallis, 1683), 7. 
26 Ibid., 15-16.

27 Ibid., 72.

28 Elspeth Graham, 'Authority, Resistance and Loss: Gendered Difference in the Writings of John Bunyan and Hannah Allen', in Anne Laurence, W. R. Owens and Stuart Sim (eds), John Bunyan and His England 1628-88 (London: Hambledon Press, 1990), 115-30 (124).

29 Allen, A Narrative of God's Gracious Dealings, 71. On this point, see Elspeth Graham, 'Women's Writing and the Self', in Helen Wilcox (ed.), Women and Literature in Britain 1500-1700 (Cambridge: Cambridge University Press, 1996), 209-33 (217-20).

30 On the affective contours of Trapnel's faith, and their links to her apprehension of the 'free grace' of God, see Hilary Hinds, 'Soul-Ravishing and SinSubduing: Anna Trapnel and the Gendered Politics of Free Grace', Renaissance and Reformation, 25:4 (2001), 117-37.

31 Anna Trapnel, A Legacy for Saints (London: Thomas Brewster, 1654), 32.

32 Debora Kuller Shuger, 'Nursing Fathers: Patriarchy as a Cultural Ideal', in her Habits of Thought in the English Renaissance: Religion, Politics and the Dominant Culture (Berkeley: University of California Press, 1990), 220.

33 Shuger, Nursing Fathers', 223.

34 See for example Phyllis Mack, 'Women as Prophets During the English Civil War', Feminist Studies 8:1 (1982), 19-45; Christine Trevett, Women and Quakerism in the 17th Century (York: The Ebor Press, 1991); Phyllis Mack, Visionary Women: Ecstatic Prophecy in Seventeenth-Century England (Berkeley: University of California Press, 1992), 172-83, 277-8; Winter, 'Masculinities in George Fox's Journal', 151-5.

35 Michele Lise Tarter, 'Quaking in the Light: The Politics of Quaker Women's Corporeal Prophecy in the Seventeenth-Century Transatlantic World', in J. M. Lindman and M. L. Tarter (eds), A Centre of Wonders: The Body in Early America (Ithaca: Cornell University Press, 2001), 146. For further discussion of the corporeality of early Quaker public discourse, see Chapter 2.

36 Mack, 'Women as Prophets'. See too Diane Purkiss, 'Producing the Voice, Consuming the Body: Women Prophets of the Seventeenth Century', in Isobel Grundy and Susan Wiseman (eds), Women, Writing, History 1640-1740 (London: Batsford, 1992), 139-58.

37 On the Puritan dissolution of self, see Tom Webster, 'Writing to Redundancy: Approaches to Spiritual Journals and Early Modern Spirituality', The Historical Journal, 39:1 (1996), 33-56, especially 42-3; Hilary Hinds, God's Englishwomen: Seventeenth-Century Radical Sectarian Writing and Feminist Criticism (Manchester: Manchester University Press, 1996), 80-107; Mack, Visionary Women, 7-8.

38 On the significance of the chronological structure of Fox's text, see Chapter 4. On conversion narrative, see Owen C. Watkins, The Puritan Experience: Studies in Spiritual Autobiography (London: Routledge and Kegan Paul, 1972); Patricia Caldwell, The Puritan Conversion Narrative: The Beginnings of American Expression (Cambridge: Cambridge University Press, 1985); D. Bruce Hindmarsh, The Evangelical Conversion Narrative: Spiritual Autobiography in Early Modern England (Oxford: Oxford University Press, 2005). 
39 George Fox, The Journal, ed. Nigel Smith (London: Penguin, 1998), 4.

40 Ibid., 4, 6.

41 Ibid., 7.

42 Ibid., 8.

43 Ibid., 6, 12.

44 Ibid., 8.

45 Ingle, First Among Friends, 40.

46 Fox, Journal, ed. Smith, 10, 11.

47 Ibid., 27.

48 Ibid., 29.

49 Ibid., 33. On Fox's redefinition of election and reprobation, see ibid., 69, 76, 176, and especially 240: 'they [i.e. priests and professors] had frightened people with the doctrine of election and reprobation: and said that the greatest part of men and women God had ordained them for Hell, let them pray or preach or sing and do what they could, it was all nothing if they was ordained for hell. And God had a certain number which was elected for Heaven, let them do what they would, as David an adulterer and Paul a persecutor, yet elected vessels for Heaven. . . . So I was made to open to the people the folly of their priests' doctrines'.

50 Ibid., 33-4.

51 On the ordo salutis, see von Rohr, The Covenant of Grace; Dewey D. Wallace, Jr, 'The Doctrine of Predestination in the Early English Reformation', Church History, 43 (1974), 201-15; Dewey D. Wallace, Jr, Puritans and Predestination: Grace in English Protestant Theology, 1525-1695 (Chapel Hill: University of North Carolina Press, 1982).

52 Fox, Journal, ed. Smith, 34.

53 Ibid.

54 Ingle, First Among Friends, 42.

55 Knott, Discourses of Martyrdom, 230-1.

56 Fox, Journal, ed. Smith, 84, 67.

57 Nigel Smith, 'Introduction', in ibid., xxv.

58 Ibid., 129, 222.

59 George Fox, The Journal of George Fox, ed. John L. Nickalls (Cambridge: Cambridge University Press, 1952), 175.

60 Fox, Journal, ed. Smith, 111, 112, 116.

61 These examples are found respectively in ibid., 135, 136, 138 and 162, 138 and 218.

62 Ibid., 137.

63 Ibid., 218.

64 Fox, Journal, ed. Nickalls, 308.

65 Ibid., 175, 263.

66 Ibid., 174.

67 Fox, Journal, ed. Smith, 109.

68 Ibid., 90, 97, 98, 124, 259-62. The Lancaster trial is recounted on 105-6, though this narrative account is brief; the complete extant transcript of the trial can be found in Fox, Journal, ed. Penney, I.63-70, and an abbreviated account of the trial 
transcript is included in Fox, Journal, ed. Nickalls, 133-5. Fox's trials in Carlisle and Launceston can be found respectively in Fox, Journal, ed. Smith, 123-5, 185-91.

69 Fox, Journal, ed. Smith, 137.

70 Ibid., 111.

71 Ibid., 115.

72 Ibid., 64, 134.

73 Ibid., 33, 76.

74 Ibid., 121.

75 See Chapter 1 for a discussion of this process of 'discernment'.

76 Fox, Journal, ed. Nickalls, 134.

77 Fox, Journal, ed. Smith, 257-8. On Fox's doctrine of 'celestial inhabitation', or christopresentism, and the concomitant notion of 'celestial flesh', see Richard G. Bailey, 'The Making and Unmaking of a God: New Light on George Fox and Early Quakerism', in Mullett (ed.), New Light on George Fox, 110-28. For a fuller exposition of his analysis, see Richard Bailey, New Light on George Fox and Early Quakerism: The Making and Unmaking of a God (San Francisco: Mellen Research University Press, 1992).

78 Webster, 'Writing to Redundancy', 43.

79 Ibid.

80 Fox, Journal, ed. Smith, 127. On Quaker perfectionism, see Braithwaite, Beginnings of Quakerism, 107-10; Geoffrey Nuttall, The Holy Spirit in Puritan Faith and Experience (Oxford: Basil Blackwell, 1947), 51-5; Doncaster, 'Early Quaker Thought on "That State in which Adam was before he Fell"'; Hugh Barbour, The Quakers in Puritan England (New Haven: Yale University Press, 1964), 149-50; J. William Frost, 'The Dry Bones of Quaker Theology', Church History, 39:4 (1970), 503-23, see especially 513-20; T. L. Underwood, Primitivism, Radicalism, and the Lamb's War: The Baptist-Quaker Conflict in Seventeenth-Century England (Oxford: Oxford University Press, 1997), 60-1; Bailey, New Light on George Fox, 25-7, 63-5; 94, 99-100, 115, 124; Max L. Carter, 'Early Friends and the Alchemy of Perfection', Journal of the Friends' Historical Society, 58:3 (1999), 235-50.

81 Fox, Journal, ed. Nickalls, 159.

82 Ibid., 134.

83 Ibid.

84 Fox, Journal, ed. Smith, 34.

85 Ibid., 178.

86 For an analysis of the importance of the difference between claiming equality with, and claiming unity with, the divine at Fox's trial for blasphemy in Lancaster in 1652, see Bailey, New Light on George Fox, 102-10.

87 Compare these two OED definitions of 'agent': 'B. 1. a. One who (or that which) acts or exerts power, as distinguished from the patient, and also from the instrument'; and '4. a. Of persons: One who does the actual work of anything, as distinguished from the instigator or employer; hence, one who acts for another, a deputy, steward, factor, substitute, representative, or emissary'. While Greenblatt's formulation of the dream of unshakable masculine self-sufficiency 
reifies the subject as agent in the first of these senses, so Fox's position of potent masculine agency is activated by the latter.

88 Fox, Journal, ed. Nickalls, 99.

89 Ibid., 131.

90 Fox, Journal, ed. Smith, 129.

91 I owe this observation on the saintliness of the emaciated and infantilised body to a paper given by Michele Moatt (Lancaster University), entitled 'Monstrous Bodies and the Glory to Come: An Examination of the Food-Body Discourse of the Twelfth Century Monastic Reform Movement', at the 'Sacred and Profane Identities' conference, Groningen, Netherlands, November 2005.

92 Winter, 'Masculinities in George Fox's Journal', 148.

93 Ibid., 147. Fox, Journal, ed. Smith, 105-6, 185-90, 258-62, 101-2.

94 Isabel Ross, Margaret Fell: Mother of Quakerism, (York: The Ebor Press, 2nd ed., 1984), 214-15.

95 Fox, Journal, ed. Smith, 402.

96 For discussions of Quaker ideas about marriage, as well as about the marriage of Fox and Fell, see Caroline Whitbeck, 'Friends Historical Testimony on the Marriage Relationship', Friends Journal, 35.6 (1989), 13-15, and Mack, Visionary Women, 226-32.

97 Fox, Journal, ed. Smith, 402.

98 Ross, Margaret Fell, 213-19.

99 For a discussion of going naked as a sign, see Chapter 2, 51-2.

100 Fox, Journal, ed. Smith, 5.

101 For a much-cited ecstatic letter from Fell to Fox, see Elsa F. Glines, Undaunted Zeal: The Letters of Margaret Fell (Richmond, IN: Friends United Press, 2003), 9-11. For an account of the evidence that Fell might have thought herself to be pregnant, see Ingle, First Among Friends, 228, 342-3n.105.

102 Greenblatt, Renaissance Self-Fashioning, 9.

103 Paul Delany, British Autobiography in the Seventeenth Century (London: Routledge and Kegan Paul, 1969), 35. See too Roger Pooley, 'Grace Abounding and the New Sense of Self', in Laurence, Owens and Sim (eds), John Bunyan and his England, 105-14.

104 Fox, Journal, ed. Nickalls, 346, 346-7.

105 Ibid., 347-8.

106 Fox, Journal, ed. Smith, 268.

107 Ibid., 273.

108 Ibid., 410, 412. These two episodes of doubt and spiritual assault both coincided with periods of social and political instability and turbulence; see Braithwaite, Second Period of Quakerism, 265, 437; H. Larry Ingle, 'Richard Hubberthorne and History: The Crisis of 1659', Journal of the Friends' Historical Society, 56:3 (1992), 189-200. While it is tempting to read Fox's bodily and mental disturbances as an internal concomitant of these external crises, it is also the case that Quakerism was the product of a social, political and religious matrix of profound unrest and instability, so that it is, ultimately, difficult to find any absolute qualitative dividing line between these years and others. 
109 Fox, Journal, ed. Smith, 109.

110 Winter, 'Masculinities in George Fox's Journal', 155.

\section{Chapter 4}

An earlier version of this chapter was co-authored with Alison Findlay and published as 'The Journal of George Fox: A Technology of Presence', Quaker Studies, 12:1 (2007), 89-106. I am very grateful for her permission to include this work in this book.

1 George Fox, The Journal of George Fox, 2 vols, ed. Norman Penney (Cambridge: Cambridge University Press, 1911), II.347-8.

2 Fox, Journal, ed. Penney, I.xiii.

3 George Fox, A Journal or Historical Account of the Life, Travels, Sufferings, Christian Experiences and Labour of Love in the Work of the Ministry of that Ancient, Eminent and Faithful Servant of Jesus Christ, George Fox (London: Printed for Thomas Northcott, 1694).

4 Geoffrey Nuttall, 'Introduction', in George Fox, The Journal of George Fox, ed. John L. Nickalls (Cambridge: Cambridge University Press, 1952), xxx.

5 H. Larry Ingle, 'Unravelling George Fox: The Real Person', in Michael Mullett (ed.), New Light on George Fox 1624-1691 (York: The Ebor Press, 1994), 36-44 (38).

6 David Boulton, 'Public Policy and Politics in Fox's Thought: The Un-militant Tendency in Early Quakerism', in Mullett (ed. ), New Light on George Fox, 144-52 (144); John R. Knott, Discourses of Martyrdom in English Literature, 1563-1694 (Cambridge: Cambridge University Press, 1993), 231.

7 Nigel Smith, 'Introduction', in George Fox, The Journal, ed. Nigel Smith (London: Penguin, 1998), xi.

8 Knott, Discourses of Martyrdom, 233-5.

9 H. Larry Ingle, 'George Fox, Historian', Quaker History, 83:1 (1993), 28-35 (32).

10 Thomas N. Corns, “'No Man's Copy”: The Critical Problem of Fox's Journal, in Thomas N. Corns and David Loewenstein (eds), The Emergence of Quaker Writing: Dissenting Literature in Seventeenth-Century England (London: Frank Cass, 1995), 99-111 (110).

11 Geoffrey Nuttall, 'Reflections on William Penn's Preface to George Fox's Journal', Journal of the Friends' Historical Society, 57:2 (1995), 113-17 (113).

12 Nuttall, 'Introduction', in Fox, Journal, ed. Nickalls, 114.

13 Corns, 'No Man's Copy', 110.

14 Michel Foucault, 'On the Genealogy of Ethics: An Overview of Work in Progress', in Paul Rabinow (ed.), The Foucault Reader (London: Penguin, 1984), 340-72 (341); Tom Webster, 'Writing to Redundancy: Approaches to Spiritual Journals and Early Modern Spirituality', The Historical Journal, 39:1 (1996), 33-56 (40).

15 Claire Tomalin, Samuel Pepys: The Unequalled Self (London: Penguin, 2003), xxxviii.

16 See especially Francis Barker, The Tremulous Private Body: Essays on Subjection (London: Methuen, 1984); for a critique of such an approach, see David Aers, 'A 
Whisper in the Ear of Early Modernists; or, Reflections on Literary Critics Writing the "History of the Subject", in David Aers (ed.), Culture and History 1350-1600: Essays on English Communities, Identities and Writing (Hemel Hempstead: Harvester Wheatsheaf, 1992), 177-202.

17 Fox, Journal, ed. Smith, 89.

18 Webster, 'Writing to Redundancy', 55.

19 Fox, Journal, ed. Smith, 101-2. I am particularly indebted to Alison Findlay for the subsequent analysis of this passage.

20 For an analysis of the extent to which the account offered by Fox's Journal is shaped by later events and priorities, see Corns, 'No Man's Copy', 104-10.

21 Stuart Sherman, Telling Time: Clocks, Diaries, and English Diurnal Form, 1660-1785 (Chicago: University of Chicago Press, 1996), 33-4.

22 Ibid., 58-9.

23 Christopher Hill wrote of Fox's Journal that 'the story looks different when you know, or think you know, how it ended: when your object in writing is not merely to produce a correct record but to edify and confirm in their faith people living at the end of the story, for whom the beginning meant little'; The World Turned Upside Down: Radical Ideas During the English Revolution (London: Maurice Temple Smith, 1972; this ed. Harmondsworth: Penguin: 1975), 231.

24 William Penn, 'The preface, being a summary account of the divers dispensations of God to men, from the beginning of the world to that of our present age', in Fox, A Journal or Historical Account, n.pag.

25 OED: 'Annals', 1, 2.

26 Hayden White, 'The Value of Narrativity in the Representation of Reality', in The Content of the Form: Narrative Discourse and Historical Representation (Baltimore: Johns Hopkins University Press, 1987), 1-25 (5, 11).

27 Ibid., 8.

28 Ibid.

29 Fox, Journal, ed. Smith, 3.

30 Frank Kermode, The Sense of an Ending: Studies in the Theory of Fiction (New York: Oxford University Press, 1967), 47-8.

31 The end of time is most explicitly prophesied in Revelation 10. 5-6: "And the angel which I saw stand upon the sea and upon the earth lifted up his hand to heaven, And sware by him that liveth for ever and ever, who created heaven, and the things that therein are, and the earth, and the things that therein are, and the sea, and the things which are therein, that there should be time no longer'. For other biblical examples of kairotic time, see (as well as those cited by Kermode) Galatians 4.4 'But when the fulness of the time was come, God sent forth his Son, made of a woman, made under the law'.

32 Penn, 'Preface', Ar.

33 Richard Bailey, New Light on George Fox and Early Quakerism: The Making and Unmaking of a God (San Francisco: Mellen Research University Press, 1992), 12.

34 Bailey, New Light on George Fox, 20, my emphasis. Pink Dandelion, The Liturgies of Quakerism (Aldershot: Ashgate, 2005), 13. See too Douglas Gwyn's formulation of the complex merging of temporalities in early Quakerism: 'Fox describes the 
life of faith - out of time (or history) as a primary reference, yet still in time and through time. . . Fox's description of this entry into the new age, even while one is still engaged with the old age, suggests a relationship between the two in which they do not simply join end to end (as one year succeeds another), but in which the new age diverges from the old into a new dimension of experience' (Douglas Gwyn, Apocalypse of the Word: The Life and Message of George Fox (1624-1691) (Richmond, IN: Friends United Press, 1986), 117, his emphasis). Pink Dandelion reaches a similar conclusion in his fascinating and comprehensive discussion of Quaker temporalities: 'The Quaker experience is thus temporal, in that they engage with the world, and meta-temporal in their relationship with Christ the Word. All is headed towards a global meta-temporality where heaven is realised on earth and time and history, and the Church as it has been known, ends'; Dandelion, The Liturgies of Quakerism, 19; see too chapter 1, 'The end of time and the beginning of Quakerism', passim. For an important early discussion of Quaker temporality, see Jackson I. Cope, 'Seventeenth-Century Quaker Style', PMLA, 71 (1956), 725-54 (744-9).

35 T. L. Underwood, Primitivism, Radicalism, and the Lamb's War: The Baptist-Quaker Conflict in Seventeenth-Century England (Oxford: Oxford University Press, 1997), 5.

36 Ibid., 4-5.

37 Fox, Journal, ed. Smith, 44-5.

38 Underwood, Primitivism, Radicalism, and the Lamb's War, 4.

39 Fox, Journal, ed. Smith, 86.

40 Ibid., 96.

41 On Quaker conceptualisation of 'inward and 'outward, see M. A. Creasey, " Inward" and "Outward": A Study in Early Quaker Language', Journal of the Friends' Historical Society, supplement no. 30 (1962), 1-24.

42 Sherman, Telling Time, 43, 34.

43 Fox, Journal, ed. Smith, 441.

44 OED: 'Journal', 2a, 2b, 3, 4.

45 Nigel Smith, 'Border Crossings: Fox's Journeys in an International Context'; unpublished conference paper delivered at 'Early Quaker Networks and the Politics of Place 1652-1672' conference, Lancaster, 1 May 2004, 4.

46 'Alice Cobb's Testimony concerning her Mother Alice Curwen', in Alice Curwen, A Relation of the Labour, Travail and Suffering of that faithful Servant of the Lord Alice Curwen (London: s.n., 1680), n.pag; original italics.

47 Sherman, Telling Time, 59.

48 Smith, 'Border Crossings', 2.

49 Michael Mascuch, Origins of the Individualist Self: Autobiography and Self-Identity in England, 1591-1791 (Cambridge: Polity Press, 1997), 233n.66.

50 Smith, 'Introduction', in Fox, Journal, ed. Smith, xxii.

51 See Sherman on the formulation 'and so' in Pepys's Diary: Telling Time, 68.

52 Fox, Journal, ed. Smith, 102, 106, 274.

53 Ibid., 102, 101-2.

54 In this regard, Gwyn's analysis of Fox's habit of combining the past and present (though tellingly, not the future) tense of verbs is pertinent: 'The vital and 
triumphant message of Quakerism is that the work has already begun. Fox expresses this repeatedly in his proclamations that Christ "is come and coming to reign", "the church in her glory and beauty is appeared and appearing" .... With this figure of speech, he grounds ultimate future in an unfolding present'; Gwyn, Apocalypse of the Word, 206.

55 Webster, 'Writing to Redundancy', 43; James Nayler, Love to the Lost: And a Hand Held Forth to the Helpless, to lead out of the Dark (London: printed for Giles Calvert, 1656), 56.

56 Henry J. Cadbury, 'George Fox's Later Years', in Fox, Journal, ed. Nickalls, 755, 754.

57 Kermode, Sense of an Ending, 26, 58.

\section{Chapter 5}

1 Grace Tiffany, Love's Pilgrimage: The Holy Journey in English Renaissance Literature (Newark, NJ: University of Delaware Press, 2006), 29.

2 On the terms 'Public Friends' and 'Publishers of Truth', see 156n.16.

3 Edward Burrough, 'A Faithful Testimony Concerning the True Worship of God' (1659), in The Memorable Works of a Son of Thunder and Consolation (s.1.: s.n., 1672), 474-82 (474).

4 George Fox, The Journal, ed. Nigel Smith (London: Penguin, 1998), 3.

5 Ibid.

6 Ibid., 25. Fox is here also alluding to Matthew 10.7: 'And as ye go, preach, saying, The kingdom of heaven is at hand'.

7 Fox, Journal, ed. Smith, 6. For Fox's last journey overseas, to Holland in 1684, see Henry J. Cadbury, 'George Fox's Later Years', in George Fox, The Journal of George Fox, ed. John L. Nickalls (Cambridge: Cambridge University Press, 1952), 713-56 (730-1); H. Larry Ingle, First Among Friends: George Fox and the Creation of Quakerism (Oxford: Oxford University Press, 1994), 277.

8 Hugh Barbour, The Quakers in Puritan England (New Haven: Yale University Press, 1964), 72. For accounts of these early journeys, see William C. Braithwaite, The Beginnings of Quakerism (Cambridge: Cambridge University Press, 2nd ed., 1955), 51-129; Ingle, First Among Friends, 72-106; Rosemary Moore, The Light in Their Consciences: Early Quakers in Britain 1646-1666 (University Park, PA: Pennsylvania State University Press, 2000), 3-34.

9 Braithwaite, Beginnings of Quakerism, 66.

10 The estimate was made using the 1655 journeys as identified in Nigel Smith's edition of the Journal together with Google maps. The distance cannot be given more precisely because Fox's list of places visited is incomplete and at times imprecise; sometimes, for example, he records only that he went into Nottinghamshire or Derbyshire, and at others that he visited 'another town'.

11 On the relationship between Quakers and Seekers, see Braithwaite, Beginnings of Quakerism, 25-7; Barbour, The Quakers in Puritan England, 30-2. On the origins of the movement more generally, see Braithwaite, Beginnings of Quakerism, chapter 1; 
Barbour, The Quakers in Puritan England, chapters 2 and 3; Ingle, First Among Friends, 81-6; Richard T. Vann, The Social Development of English Quakerism 1655-1755 (Cambridge, MA: Harvard University Press, 1969), 10-32; Barry Reay, The Quakers and the English Revolution (London: Temple Smith, 1985), 7-45; Moore, Light in Their Consciences, 3-34; Catie Gill, Women in the Seventeenth-Century Quaker Community: A Literary Study of Political Identities, 1650-1700 (Aldershot: Ashgate, 2005), 11-40.

12 Kate Peters analyses the importance of print in the establishment of the early movement and its networks; see her Print Culture and the Early Quakers (Cambridge: Cambridge University Press, 2005), especially chapters 1-3. See too Thomas O’Malley, 'The Press and Quakerism 1653-1659', Journal of the Friends' Historical Society, 54 (1979), 169-84. On travel and support networks and methods, see Barbour, The Quakers in Puritan England, 51-3; Vann Social Development, 10-12, 97-101; and Moore, Light in Their Consciences, 25-30. On the importance of itinerant ministers to the early movement, see Frederick B. Tolles, Quakers and the Atlantic Culture (New York: Macmillan, 1960), 24-9, and Moore, Light in Their Consciences, 13-15, 25-8. See too Barbara Ritter Dailey, 'The Itinerant Preacher and the Social Network in Seventeenth-Century New England', in Peter Benes (ed.), Itinerancy in New England and New York. The Dublin Seminar for New England Folklife: Annual Proceedings 1984 (Boston: Boston University, 1986), 37-48.

13 For more details of these (and other) Friends and their journeys, see Braithwaite, Beginnings of Quakerism, 153-205; 401-33; Moore, Light in Their Consciences, 34; Rufus M. Jones, The Quakers in the American Colonies (New York: W.W. Norton, 1966); Sylvia Brown, 'The Radical Travels of Mary Fisher: Walking and Writing in the Universal Light', in Sylvia Brown (ed.), Women, Gender and Radical Religion in Early Modern Europe (Leiden, Boston: Brill, 2007) 39-64; Sünne Juterczenka, 'Crossing Borders and Negotiating Boundaries: The Seventeenth-Century European Missions and Persecution', Quaker Studies, 12:1 (2007), 39-53. Norman Penney (ed.), The First Publishers of Truth: Being Early Records (Now First Printed) of the Introduction of Quakerism into the Counties of England and Wales. Supplement to Journal of the Friends' Historical Society, 1-5 (London: Headley Brothers, 1907), provides a fascinating and exhaustive contemporary insight into the early Quaker itinerant ministry, as does Joseph Besse, A Collection of the Sufferings of the People called Quakers, 2 vols (London: printed and sold by Luke Hinde, 1753).

14 Quoted in Braithwaite, Beginnings of Quakerism, 337.

15 Michael Watts, The Dissenters: From the Reformation to the French Revolution (Oxford: Oxford University Press, 1978), 198. For further discussion of the extent of Quaker geographical ambitions, including Fox's letter to the Emperor of China, see Barbour, The Quakers in Puritan England, 67-70.

16 Tolles, Quakers and the Atlantic Culture, 27.

17 Fox, Journal, ed. Smith, 5, 12; see too 7.

18 Ibid., 12.

19 Ibid., 6; see too 10, 12.

20 Ibid., 16. 
21 Ibid., 33; 39; 350. For further references in the Journal to fields, see 61, 73-4, 91, 160, 219; and to hills see 83, 127, 128, 143, 229-30, 235.

22 On contemporary understandings of prophecy, see Geoffrey F. Nuttall, The Holy Spirit in Puritan Faith and Experience (Oxford: Basil Blackwell, 1947), 75-89; Nigel Smith, Perfection Proclaimed: Language and Literature in English Radical Religion 1640-1660 (Oxford: Clarendon Press, 1989), especially 23-103; Elaine Hobby, 'Prophecy, Enthusiasm and Female Pamphleteers', in N. H. Keeble (ed.), The Cambridge Companion to Writing of the English Revolution (Cambridge: Cambridge University Press, 2001), 162-78; Hilary Hinds, 'Prophecy and Religious Polemic', in Laura Lunger Knoppers (ed.), The Cambridge Companion to Early Modern Women's Writing (Cambridge: Cambridge University Press, 2009), 235-46. More generally, see Bertrand Taithe and Tim Thornton (eds), Prophecy: The Power of Inspired Language in History 1300-2000 (Stroud, Gloucestershire: Sutton Publishing, 1997).

23 Fox, Journal, ed. Smith, 5, 12.

24 Ibid., 66.

25 Ibid., 127, 109.

26 Ibid., 197.

27 Ibid.

28 A. L. Beier, Masterless Men: The Vagrancy Problem in England 1560-1640 (London: Methuen, 1985), 140.

29 J. F. McGregor, 'The Baptists: Fount of All Heresy', in J. F. McGregor and B. Reay (eds), Radical Religion in the English Revolution (Oxford: Oxford University Press, 1984), 26-8; see too Murray Tolmie, The Triumph of the Saints: The Separate Churches of London 1616-1649 (Cambridge: Cambridge University Press, 1977).

30 Christopher Hill, The World Turned Upside Down: Radical Ideas During the English Revolution (London: Maurice Temple Smith, 1972; this ed. Harmondsworth: Penguin: 1975), 27.

31 Hill, World Turned Upside Down, 49, 85.

32 Thomas N. Corns, 'Bunyan, Milton and the Diversity of Radical Protestant Writing', in N. H. Keeble (ed.), John Bunyan: Reading Dissenting Writing (Oxford, Bern: Peter Lang, 2002), 32; Corns is referring here to Milton's 'Considerations Touching the Likeliest Means to Remove Hirelings out of the Church' (1659); see Milton, Complete Prose Works, 8 vols, ed. Don M. Wolfe (New Haven, CT: Yale University Press, 1953-1982), VII.273-321; see especially 304-5.

33 Beier, Masterless Men, 140-1.

34 On Coppin, see ODNB; Hill, World Turned Upside Down, 220-3; Lawrence Clarkson, A Single Eye All Light, no Darkness; or Light and Darkness One (London, 1650), A2r; Anna Trapnel's journey to Cornwall is recounted in her Anna Trapnel's Report and Plea (London: Thomas Brewster, 1654); Elinor Channel, A Message from God, by a Dumb Woman (1653) is included as an appendix in Hilary Hinds, God's Englishwomen: Seventeenth-Century Radical Sectarian Writing and Feminist Criticism (Manchester: Manchester University Press, 1996), 219-21. Religious itinerancy was not only an English phenomenon in the seventeenth century. Wanderers, Michel de Certeau notes, 'abounded during that period in which the Churches ceased organizing space and before a political order was in firm control. There are 
all sorts of wanderers, from the little passersby . . . to the great itinerants'; Michel de Certeau, The Mystic Fable. Volume One: The Sixteenth and Seventeenth Centuries, trans. Michael B. Smith (Chicago: University of Chicago Press, 1992), 292.

35 On the place of itinerancy in the constitution of the perceived 'Quaker menace', see Leo Damrosch, The Sorrows of the Quaker Jesus: James Nayler and the Puritan Crackdown on the Free Spirit (Cambridge, MA: Harvard University Press, 1996), 37-52; see too Moore, Light in Their Consciences, 124-6.

36 'To the Right Worshipfull the Justices of the Peace for the County of Westmorland', in James Nayler, Several Petitions Answered, That were put up by the Priests of Westmorland, Against James Nayler and Geo. Fox (London: printed for Giles Calvert, 1653), 1-2 (1).

37 Francis Higginson, A Brief Relation of the Irreligion of the Northern Quakers (London: printed by T. R. for H. R., 1653), 1.

38 Ibid., 35; his italics. Higginson is quoting from John Owen, A sermon preached to the Honourable House of Commons, in Parliament assembled: on January 31. A day of solemne humiliation. With a discourse about toleration, and the duty of the civill magistrate about religion, thereunto annexed. Humbly presented to them, and all peace-loving men of this nation (London, printed by Matthew Simmons, 1649). The passage quoted by Higginson is taken not from page 32 of Owen's text, as he suggests, but from page 82. Owen was a theologian and Independent minister, whose sermon quoted here was delivered to the Commons on the day after the regicide, which he supported as a just restraint on a monarch's misrule. Interestingly, in the context of Higginson's citation of him in this context, Owen's appendix to the text argued for religious toleration, 'though he acknowledged the state's right to punish heretics and schismatics who disrupted the peace or employed violence to thwart the gospel's progress' (ODNB).

39 Higginson, Irreligion of the Northern Quakers, 28. A journeyman was 'a mechanic who has served his apprenticeship or learned a trade or handicraft, and works at it not on his own account but as the servant or employee of another'; it was also used pejoratively to refer to a hireling or drudge, or someone who was not a 'master' of his trade (OED 1, 2a, 2b).

40 William Prynne, The Quakers Unmasked, And clearly detected to be but the Spawn of Romish Frogs, Jesuites, and Fransciscan Fryers (London: Edward Thomas, 2nd ed., 1655), title page, $1,2$.

41 St. 39 Eliz. Cap. 4. Phyllis Mack, Visionary Women: Ecstatic Prophecy in SeventeenthCentury England (Berkeley: University of California Press, 1992), 445.

42 William C. Braithwaite, 'The Penal Laws Affecting Early Friends in England', in Penney, First Publishers of Truth, 347.

43 Fox, Journal, ed. Smith, 74, 101.

44 Joseph A. Amato, On Foot: A History of Walking (New York: New York University Press, 2004), 45. See too Mark 6.7-9 and Luke 9.2-4.

45 Fox, Journal, ed. Smith, 6. The allusion here is to Christ's words in Luke 14.26: 'If any man come to me, and hate not his father, and mother, and wife, and children, and brethren, and sisters, yea, and his own life also he cannot be my disciple'.

46 James Nayler, A Collection of Sundry Books, Epistles and Papers Written by James Nayler (London: J. Sowle, 1716), 12, 186; his italics. 
47 T. T. [Theophila Townsend], A Testimony Concerning the Life and Death of Jane Whitehead. That Faithful Servant and Hand-maid of the Lord (London: s.n., 1676), 12, 13.

48 Susan Wiseman, 'Read Within: Gender, Cultural Difference and Quaker Women's Travel Narratives', in Kate Chedgzoy, Melanie Hansen, and Suzanne Trill (eds), Voicing Women: Gender and Sexuality in Early Modern Writing (Keele: Keele University Press, 1996; this ed: Edinburgh: Edinburgh University Press, 1998), 153-71 (154). Wiseman's sense of 'Quaker self-mythologization' accords with de Certeau's suggestion that 'What this walking exile produces is precisely the body of legends that is currently lacking in one's own vicinity; it is a fiction'; Michel de Certeau, The Practice of Everyday Life, trans. Steven Rendell (Berkeley: University of California Press, 1984), 107.

49 Bonnelyn Young Kunze, Margaret Fell and the Rise of Quakerism (Basingstoke: Macmillan, 1994), 153.

50 Wiseman, 'Read Within', 156. She is discussing Barbara Blaugdone, An account of the travels, sufferings and persecutions of Barbara Blaugdone (London: printed and sold by T. S., 1691).

51 Quoted in Mack, Visionary Women, 224.

52 See Braithwaite, Beginnings of Quakerism, 241-78; Damrosch, Sorrows of the Quaker Jesus, chapter 3 passim; Moore, Light in Their Consciences, 35-48.

53 Damrosch, Sorrows of the Quaker Jesus, 222-6. On the skimmington ride, see Martin Ingram, 'Ridings, Rough Music and the "Reform of Popular Culture" in Early Modern England', Past and Present, 105:1 (1984), 79-113; David Underdown, 'The Taming of the Scold: The Enforcement of Patriarchal Authority in Early Modern England', in A. J. Fletcher and J. Stevenson (eds), Order and Disorder in Early Modern England (Cambridge: Cambridge University Press, 1985), 116-36; David Underdown, Revel, Riot and Rebellion (Oxford: Oxford University Press, 1985).

54 On the rhetoric of the 'preposterous' - that is, of reversal or inversion - see Patricia Parker, 'Spelling Backwards', in Jennifer Richards and Alison Thorne (eds), Rhetoric, Women and Politics in Early Modern England (London: Routledge, 2007), 25-50.

55 This notwithstanding, see an analysis of Quaker gait and posture in Adrian Davies, The Quakers in English Society 1655-1725 (Oxford: Clarendon Press, 2000), 58-60.

56 Eric J. Leed, The Mind of the Traveler: From Gilgamesh to Global Tourism (New York: Basic Books, 1991), 73-4.

57 Fox, Journal, ed. Smith, 158-9.

58 For an analysis of this aspect of Fox's prose, see Smith, 'Introduction', in Fox, Journal, ed. Smith, $\mathrm{xx}-\mathrm{xxv}$.

59 Higginson, Irreligion of the Northern Quakers, 28; OED: ‘journeyman': 1.

60 The complete extant transcript of the trial can be found in George Fox, The Journal of George Fox, 2 vols, ed. Norman Penney (Cambridge: Cambridge University Press, 1911), I.63-70; see too Penney's note on the trial on 412. An abbreviated account of the trial transcript is included in Fox, Journal, ed. Nickalls, 133-5.

61 Thomas Corns argues that Fox 'may have sought to offer a sanitized version of Quakerism more suitable in the puritan winter of the 1660s and early 1670s. But 
any such tendency is unsustained. The legacy he left for his literary executors to sort out was too fissured, too contradictory, too retentive of earlier sentiments and evidence to be rendered quite coherent even by the assiduous Ellwood'; Thomas N. Corns, "'No Man's Copy”: The Critical Problem of Fox's Journal', in Thomas N. Corns and David Loewenstein (eds), The Emergence of Quaker Writing: Dissenting Literature in Seventeenth-Century England (London: Frank Cass, 1995), 99-111 (110).

62 Braithwaite, Beginnings of Quakerism, 401.

63 de Certeau, Mystic Fable. 299. Smith, de Certeau's translator, explains his translation of 'la mystique' as mystics: 'This term cannot be rendered accurately by the English word "mysticism," which would correspond rather to the French le mysticisme, and be far too generic and essentialist a term to convey the historical specificity of the subject of this study. . . . I have, therefore, in extremis, adopted the bold solution of introducing a made-up English term, mystics (always in italics, to distinguish it from the plural of "a mystic"), to render la mystique, a field that might have won (but never did, in English) a name alongside metaphysics, say, or optics' (ix-x). Accordingly, I follow Smith's lead in italicising mystics in this discussion of de Certeau's work. There is a longstanding debate in Quaker studies about the accuracy and aptness of conceptualising Quakerism within a tradition of mysticism as opposed to a tradition of Protestantism or radical Puritanism. The former position is usually routed back to the work of Rufus M. Jones, in Studies in Mystical Religion (s.1.: MacMillan, 1909) and Spiritual Reformers in the 16th and 17th Centuries (s.1.: MacMillan, 1914), and to William C. Braithwaite; the latter is traced to, in particular, the work of Nuttall, The Holy Spirit in Puritan Faith and Experience, and Barbour, The Quakers in Puritan England. Overviews of this debate can be found in Melvin B. Endy, 'The Interpretation of Quakerism. Rufus Jones and His Critics', Quaker History: Bulletin of Friends' Historical Association, 62:1 (1981), 3-21, and Douglas Gwyn, Apocalypse of the Word: The Life and Message of George Fox (1624-1691) (Richmond, IN: Friends United Press, 1986), xiii-xix. See too Pink Dandelion, 'Introduction', 1-8; Hugh Barbour, 'Sixty Years in Early Quaker History', 19-31; and John Punshon, 'The End of (Quaker) History? Some Reflections on the Process', 32-42, all in Pink Dandelion (ed.), The Creation of Quaker Theory: Insider Perspectives (Aldershot: Ashgate, 2004). Nigel Smith discusses mid-seventeenth-century mysticism in Perfection Proclaimed: Language and Literature in English Radical Religion 1640-1660 (Oxford: Clarendon Press, 1989), 105-225; and Hugh Ormsby-Lennon considers Fox's use of language in relation to mysticism in 'From Shibboleth to Apocalypse: Quaker Speechways during the Puritan Revolution', in Peter Burke and Roy Porter (eds), Language, Self and Society: A Social History of Language (Cambridge: Polity Press, 1991), 72-112 (86-7).

64 de Certeau, Mystic Fable, 13, 5.

65 Ibid., 2; my italics.

66 Ibid., 4.

67 Ibid., 299; original italics.

68 Ibid., 8; on the terms and delineation of this analogy, see 6-9. Jacques Lacan, 'The Meaning of the Phallus', in Juliet Mitchell and Jacqueline Rose (eds), Feminine 
Sexuality: Jacques Lacan and the École Freudienne (New York: W. W. Norton, 1983), 74-85 (81).

69 de Certeau, Mystic Fable, 13.

70 Ibid., 14.

71 Fox, Journal, ed. Smith, 93.

72 See Chapter 4, 85-6, for a detailed discussion of just such a violent incident, where Fox's characteristic stillness is at the centre of, and contrasts with, the tumultuous and ungodly movement of others.

73 George Fox, Epistle 10, in A Collection of Many Select and Christian Epistles, Letters and Testimonies (London: T. Sowle, 1698), 11; reprinted in Hugh Barbour and Arthur O. Roberts (eds), Early Quaker Writings, 1650-1700 (Grand Rapids, MI: Eerdmans, 1973), 487.

74 Fox, Epistles 16, 43 and 230, in A Collection of Many Select and Christian Epistles, 14, 39, 201.

75 Fox, Journal, ed. Penney, I.224; Penney's brackets.

76 Charles Marshall, An Epistle to Friends coming forth in the Beginning of a Testimony and of the Snares of the Enemy Therein (London?: s.n., 1730?), 3-4, 4, 6. The 1844 edition of Marshall's writings dates this epistle as 1677; see Charles Marshall, The Journal, together with sundry epistles and other writings (London: Richard Barrett, 1844), 122-5. Early English Books Online notes that 'Wing (CD-ROM edition) reports date of publication as 1680'. For a detailed analysis of Marshall's preaching rhetoric, see Michael P. Graves, Preaching the Inward Light: Early Quaker Rhetoric (Waco, TX: Baylor University Press, 2009), 100-4.

77 See too Katherine Bull to Dewsbury: 'there is nothinge for me to doe but to stand stel in the obedience to the light', quoted in Barbour, The Quakers in Puritan England, 102. Edward Burrough articulated a similar sense of the struggle between spiritual stillness and carnal motion: 'while waiting upon the Lord in silence . . . being stayed in the Light of Christ within us, from all thoughts, fleshly motions, and desires, ... we received often the pouring down of the spirit upon us'; Edward Burrough, 'The Epistle to the Reader', in George Fox The Great Mistery of the Great Whore Unfolded (London: Tho: Simmons, 1659), bv-b2r.

78 Fox, Journal, ed. Smith, 83.

79 de Certeau, The Practice of Everyday Life, 101.

80 Ibid.

81 Fox, Journal, ed. Smith, 221, 173.

82 Leed, Mind of the Traveler, 54.

83 Anon. (attributed here to Sir Walter Ralegh), 'The Passionate Man's Pilgrimage', in Edward Lucie-Smith (ed.), The Penguin Book of Elizabethan Verse (Harmondsworth: Penguin, 1965), 208-10; George Herbert, 'The Pilgrimage', in The English Poems of George Herbert, ed. Helen Wilcox (Cambridge: Cambridge University Press, 2007), 494-5; Henry Vaughan, 'The Pilgrimage', in The Complete Poems, ed. Alan Rudrum (Harmondsworth: Penguin, 1976), 224-5; Robert Herrick. 'On himselfe' ('Here down my wearyed limbs Ile lay'), in The Poems of Robert Herrick, ed. L. C. Martin (London: Oxford University Press, 1965), 123; John Donne, Sonnet 6 ('This is my play's last scene'), in The Complete English Poems, ed. A. J. Smith 
(Harmondsworth: Penguin, 1971), 311; Thomas Traherne, 'Walking', in Poems, Centuries and Three Thanksgivings, ed. Anne Ridler (London: Oxford University Press, 1966), 123-4. On Protestant pilgrimage, see Tiffany, Love's Pilgrimage; N. H. Keeble, "To be a pilgrim": Constructing the Protestant Life in Early Modern England', in Colin Morris and Peter Roberts (eds), Pilgrimage: The English Experience from Becket to Bunyan (Cambridge: Cambridge University Press, 2002), 238-56; on walking and meditation in Traherne's work, see Richard Douglas Jordan, 'Thomas Traherne and the Art of Meditation', Journal of the History of Ideas, 46:3 (1985), 381-403.

84 Leed, The Mind of the Traveler, 26.

85 Fox, Journal, ed. Smith, 88.

86 Leed, The Mind of the Traveler, 44-5.

87 Fox, Journal, ed. Smith, 5.

88 Fox, Journal, ed. Smith, 333-4.

89 Ibid., 323.

90 de Certeau, The Practice of Everyday Life, 117, 118, 117; his italics.

91 de Certeau, Mystic Fable, 299.

92 Ibid., 17; his italics.

93 Ibid.

94 Priscilla Cotton and Mary Cole, 'To the Priests and People of England' (1655), in Hinds, God's Englishwomen, 222, 223.

95 Peter Stallybrass, 'The Mystery of Walking', Journal of Medieval and Early Modern Studies, 32:3 (2002), 571-80 (578).

96 Oliver Wendell Holmes, 'The Physiology of Walking', in Pages From an Old Volume of Life: A Collection of Essays, 1857-1881 (Boston: Houghton, Mifflin and Company, 1892), 121-31 (127-8).

97 de Certeau, Mystic Fable, 271; his italics.

98 Ibid., 291.

99 See too 1 John 2 for further reference to walking in the light and stumbling, and 2 John's prioritisation of journeying and presence.

\section{Chapter 6}

1 George Fox, The Journal, ed. Nigel Smith (London: Penguin, 1998), 83.

2 The phrase 'the 1652 country' is used by Friends to designate the area covered by Fox's 1652 journey from Pendle Hill to Swarthmoor Hall, near Ulverston, Cumbria.

3 On the importance of itinerancy to the early movement, see Chapter 5.

4 Fox, Journal, ed. Smith, 82-3.

5 Tolles speculates that Fox's vision of 'Lancashire sea' might be seen as indicative of the importance of the land mass across that sea, and the later Atlantic communities of Friends, to the development of the movement; Frederick B. Tolles, Quakers and the Atlantic Culture (New York: Macmillan, 1960), 4-5.

6 On the importance of place in accounts of early Quaker travels, see Susan 
Wiseman, 'Read Within: Gender, Cultural Difference and Quaker Women's Travel Narratives', in K. Chedgzoy, M. Hansen and S. Trill (eds), Voicing Women: Gender and Sexuality in Early Modern Writing (Keele: Keele University Press, 1996; this ed.: Edinburgh: Edinburgh University Press, 1998), 153-71; on the relation between text and itinerancy, see Kate Peters, 'Patterns of Quaker Authorship, 1652-6', in Thomas N. Corns and David Loewenstein (eds), The Emergence of Quaker Writing: Dissenting Literature in Seventeenth-Century England (London: Frank Cass, 1995), 6-24; and Kate Peters, Print Culture and the Early Quakers (Cambridge: Cambridge University Press, 2005).

7 On early Friends' beliefs about the indwelling light and the godliness of the regenerate body, see Chapter 1, and Geoffrey F. Nuttall, Studies in Christian Enthusiasm, Illustrated from Early Quakerism (Wallingford, PA: Pendle Hill Publications, 1948); Hugh Barbour, The Quakers in Puritan England (New Haven: Yale University Press, 1964); J. William Frost, 'The Dry Bones of Quaker Theology', Church History, 39:4 (1970), 503-23; Richard G. Bailey, New Light on George Fox and Early Quakerism: The Making and Unmaking of a God (San Francisco: Mellen Research University Press, 1992); and Michele Lise Tarter, 'Quaking in the Light: The Politics of Quaker Women's Corporeal Prophecy in the Seventeenth-Century Transatlantic World', in Janet Moore Lindman and Michele Lise Tarter (eds), A Centre of Wonders: The Body in Early America (Ithaca: Cornell University Press, 2001), 145-62.

8 Fox, Journal, ed. Smith, 86.

9 Ibid., 83.

10 Most historians take the first transatlantic Quaker travellers to have been Mary Fisher and Ann Austin. Carroll, however, argues that it may have been Elizabeth Harris; see Kenneth L. Carroll, 'Elizabeth Harris, the Founder of American Quakerism', Quaker History, 57 (1968), 96-111.

11 Accounts of Fox's journeys can be found in varying forms in the different editions of his Journal. My discussion here draws on George Fox, The Journal of George Fox, 2 vols, ed. Norman Penney (Cambridge: Cambridge University Press, 1911); The Journal of George Fox, ed. John L. Nickalls (Cambridge: Cambridge University Press, 1952); and Fox, Journal, ed. Smith. The other principal texts discussed in this chapter are Alice Curwen, A Relation of the Labour, Travail and Suffering of that faithful Servant of the Lord Alice Curwen (London: s.n., 1680); and Joan Vokins, God's Mighty Power Magnified: As Manifested and Revealed in his Faithful Handmaid Joan Vokins (London: printed for Thomas Northcott, 1691).

12 Fox, Journal, ed. Smith, 456.

13 Ibid., 461.

14 See the incomplete contemporary maps of New Jersey, Maryland, Virginia and Carolina in J. D. Black (ed.), The Blathwayt Atlas, 2 vols (Providence: Brown University Press, 1970).

15 Fox, Journal, ed. Smith, 468, 469.

16 Ibid., 463, 469, 470.

17 Tolles, Quakers and the Atlantic Culture, 12.

18 Fox, Journal, ed. Smith, 487-8. 
19 More generally, the passage alludes to the Israelites' escape from Egypt in Exodus 13, 14, 15.

20 Fox, Journal, ed. Smith, 27. On early modern readings of America in relation to the fall, see Stephen Greenblatt, Marvelous Possessions: The Wonder of the New World (Oxford: Clarendon Press, 1991); Andrew Hadfield, Literature, Travel and Colonial Writing in the English Renaissance, 1545-1625 (Oxford: Clarendon Press, 1998); Kenneth Olwig, Landscape, Nature and the Body Politic: From Britain's Renaissance to America's New World (Madison, WI: University of Wisconsin Press, 2002).

21 For discussion of the importance, and development, of the notion of 'suffering' in the movement, see John R. Knott, 'Joseph Besse and the Quaker Culture of Suffering', in Corns and Loewenstein (eds), The Emergence of Quaker Writing, 126-41.

22 Mary Louise Pratt, Imperial Eyes: Travel Writing and Transculturation (London: Routledge, 1992), 86.

23 Curwen, A Relation of the Labour, 3.

24 Ibid., 4-5; original emphasis.

25 Vokins, God's Mighty Power Magnified, 34, 35. Thomas Case, of Newtown, Long Island, set up a 'new form of Quakerism', asserting that 'he was come to perfection, and could sin no more than Christ'; Rufus M. Jones, The Quakers in the American Colonies (New York: W. W. Norton, 1966), 232.

26 Curwen, A Relation of the Labour, 2. On the executions of Friends in Massachusetts, see Jones, The Quakers in the American Colonies, 63-89.

27 Curwen, A Relation of the Labour, 12.

28 Fox, Journal, ed. Nickalls, 609-10. The italicised words were inserted by Nickalls from Fox, Journal, ed. Penney, II.255.

29 Fox, Journal, ed. Nickalls, 596. These words are John Hull's, one of Fox's travelling companions. Nickalls included this in his edition of Fox's Journal because of the lack of an account from Fox himself.

30 Fox, Journal, ed. Smith, 487.

31 Curwen, A Relation of the Labour, 6-7.

32 'An Act to prevent the People called Quakers, from bringing Negroes to their Meeting . . . whereby the safety of this Island may be hazared [sic]'; Joseph Besse, A Collection of the Sufferings of the People called Quakers, 2 vols (London: printed and sold by Luke Hinde, 1753), II.22.

33 Anon., Great Newes from the Barbadoes, or A True and Faithful account of the Grand Conspiracy of the Negroes against the English (London: printed for L. Curtis, 1676), 12.

34 Curwen, A Relation of the Labour, 6.

35 Vokins was in Barbados from January or February to April or May 1681, but it is not possible to date the duration of her stay more precisely than this from her text.

36 Vokins, God's Mighty Power Magnified, 42-3.

37 On the colonial history of Barbados, see Vincent T. Harlow, A History of Barbados 1625-1685 (New York: Negro Universities Press, 1969); Carl and Roberta Bridenbaugh, No Peace Beyond the Line: The English in the Caribbean 1624-1690 
(New York: Oxford University Press, 1972); Richard S. Dunn, Sugar and Slaves: The Rise of the Planter Class in the English West Indies, 1624-1713 (New York: W. W. Norton, 1972); Gary A. Puckrein, Little England: Plantation Society and Anglo-Barbadian Politics, 1627-1700 (New York: New York University Press, 1984); Hilary McD. Beckles, White Servitude and Black Slavery in Barbados, 1627-1715 (Knoxville: University of Tennessee Press, 1989); Larry Gragg, Englishmen Transplanted: The English Colonization of Barbados 1627-1660 (Oxford: Oxford University Press, 2003); Hilary McD. Beckles, A History of Barbados: From Amerindian Settlement to Caribbean Single Market (Cambridge: Cambridge University Press, 2nd ed., 2006); Susan Dwyer Amussen, Caribbean Exchanges: Slavery and the Transformation of English Society, 1640-1700 (Chapel Hill: University of North Carolina Press, 2007).

38 There is some debate among historians as to the timing and correlation of the introduction of sugar and of slave labour to Barbados; see Gragg, Englishmen Transplanted; Stuart B. Schwartz (ed.), Tropical Babylons: Sugar and the Making of the Atlantic World, 1450-1680 (Chapel Hill: University of North Carolina Press, 2004); Russell R. Menard, Sweet Negotiations: Sugar, Slavery, and Plantation Agriculture in Early Barbados (Charlottesville: University of Virginia Press, 2006).

39 Puckrein, Little England, 12; Dunn, Sugar and Slaves, 10. In Englishmen Transplanted, Gragg suggests that Barbados in the seventeenth century was in fact no more rapacious or brutal than other colonies; see especially 8-10. It remains the case, however, that seventeenth-century visitors described the society they found in Barbados as acquisitive, fractious, amoral and self-serving.

40 Richard Ligon, A True and Exact History of the Island of Barbados (London: Humphrey Moseley, 1657), 108.

41 Jerome S. Handler, 'Father Antoine Biet's Visit to Barbados in 1654', The Journal of the Barbados Museum and Historical Society, 32 (1967), 56-76 $(67,68)$.

42 Dunn, Sugar and Slaves, 77.

43 John Rous, A Warning to the Inhabitants of Barbadoes (London: s.n., 1656), 1; Richard Pinder, A Loving Invitation (To Repentance, and Amendment of life) Unto all the Inhabitants of the Island Barbados (London: Robert Wilson, 1660), 6-7, 7, 8.

44 George Fox, To the Ministers, Teachers, and Priests (So called, and so Stileing your Selves) in Barbadoes (London: s.n., 1672), 6, 9.

45 On the history of the Quaker presence in Barbados, see Harriet Frorer Durham, Caribbean Quakers (Hollywood, FL: Dukane Press, 1972); E. M. Shilstone, 'Some Early Records of the Friends in Barbados', The Journal of the Barbados Museum and Historical Society, 34:1 (1971): 43-57; Barbara Ritter Dailey, 'The Early Quaker Mission and the Settlement of Meetings in Barbados, 1655-1700', The Journal of the Barbados Museum and Historical Society, 39 (1991): 24-46; Larry Gragg, 'A Heavenly Visitation', History Today, February 2002: 46-51; Maris Corbin, ‘An Old Quaker Burial Ground in Barbados', Journal of the Friends' Historical Society, 60:1 (2003): 36-40; Larry Gragg, The Quaker Community on Barbados: Challenging the Culture of the Planter Class (Columbia, MO: University of Missouri Press, 2009).

46 On trade routes between England, the Caribbean and New England, see Babette M. Levy, Early Puritanism in the Southern and Island Colonies (Worcester, MA: 
American Antiquarian Society, 1960), 303; Dunn, Sugar and Slaves, 4; and Durham, Caribbean Quakers, 8.

47 Handler, 'Father Antoine Biet's Visit', 69. Gragg estimates that 'Over seventy “public Friends” visited Barbados between 1655 and 1720'; Gragg, The Quaker Community, 57.

48 Tolles, Quakers and the Atlantic Culture, 28. For a comprehensive list of Quaker visitors to Barbados, see Levy, Early Puritanism, 303; see too Gragg, The Quaker Community on Barbados.

49 For Friends' comments on their successes in Barbados, see Fox, Journal, ed. Nickalls, 609; William Edmundson, A Journal of the Life, Travels, Sufferings, and Labour of Love in the Work of the Ministry (London: Harvey and Darton, 1829), 54-5; Curwen, A Relation of the Labour, 6; Vokins, God's Mighty Power Magnified, 42-3. See too Braithwaite, Second Period, 402; Durham, Caribbean Quakers, 10; Shilstone, 'Some Early Records', 44.

50 Durham, Caribbean Quakers, 15.

51 Shilstone, 'Some Early Records', 43. Gragg, Quaker Community on Barbados, 60. There were also six women's Meetings thriving in 1677, with at least 186 Quaker women attending them: see H. J. Cadbury, '186 Barbados Quakeresses in 1677', The Journal of the Barbados Museum and Historical Society, 9:4 (1942): 195-7 (195). See too Dailey, 'The Early Quaker Mission', 36-40, on the number and size of meetings on Barbados. Regarding Barbadian demographics, Puckrein suggests that in 1652 there was a population of 18,000 whites, and 20,000 black slaves: Puckrein, Little England, 71. Dunn calculates a white population of about 23,000 in 1655 , with about 20,000 black slaves; he suggests that the white population stabilised at around 20,000 between 1660 and 1684, while the black slave population increased from 20,000 in 1655 to 46,602 in 1684 (Dunn, Sugar and Slaves, 87). See too Levy, Early Puritanism, 301.

52 Levy, Early Puritanism, 300, 301; Edmundson, Journal, 76.

53 Durham, Caribbean Quakers, 25.

54 Besse, Sufferings, II.314-18.

55 Beckles, White Servitude and Black Slavery, 130.

56 Jones, The Quakers in the American Colonies, 41. See too Henry J. Cadbury, 'George Rofe in these American Parts', Bulletin of Friends' Historical Association, 35 (1946), 17-26.

57 Durham, Caribbean Quakers, 22. By 1717, however, six years before the last of these Acts was passed, Durham notes that there were only two Quaker meetings remaining on the island, at Bridgetown and Speightstown; ibid., 31.

58 The dimensions of the island are given by Bridenbaugh, No Peace Beyond the Line, 19.

59 The 'hat controversy' resulted from John Perrot's argument that Friends should remove their hats during prayer only if directly moved by God to do so, while Fox and most other Friends maintained that it was necessary to remove the hat at such times as a mark of humility before God; see Braithwaite, Second Period, 228-50; Kenneth L. Carroll, John Perrot, Early Quaker Schismatic. Journal of the Friends' Historical Society, Supplement 33 (London: Friends' Historical Society, 
1971); Nigel Smith, 'Exporting Enthusiasm: John Perrot and the Quaker Epic', in Thomas Healy and Jonathan Sawday (eds), Literature and the English Civil War (Cambridge: Cambridge University Press, 1990), 248-64; H. Larry Ingle, First Among Friends: George Fox and the Creation of Quakerism (Oxford: Oxford University Press, 1994), 197-205; Rosemary Moore, The Light in Their Consciences: The Early Quakers in Britain 1646-1666 (University Park, PA: Pennsylvania State University Press, 2000), 193-208. On Perrot's reception in Barbados, see Carroll, John Perrot, 66-71.

60 Braithwaite, Second Period, 237, 239.

61 Geoffrey F. Nuttall, 'The Last of James Nayler: Robert Rich and the Church of the First Born', Friends' Quarterly, 60 (1965): 527-34 (530-1). John Story and John Wilkinson resisted Fox's system of formalised meetings, arguing that this ran counter to the movement's reliance on individual spiritual guidance; see William C. Braithwaite, The Second Period of Quakerism (Cambridge: Cambridge University Press, 2nd ed., 1961), 290-323; Ingle, First Among Friends, 252-65; Nigel Smith, 'Hidden Things Brought to Light: Enthusiasm and Quaker Discourse', in Corns and Loewenstein (eds), The Emergence of Quaker Writing, 57-69.

62 Braithwaite, Second Period, 348, 349.

63 Ingle, First Among Friends, 234.

64 Dunn, Sugar and Slaves, 23-4.

65 Puckrein, Little England, 104.

66 George Gardyner, A Description of the New World. Or, America Islands and Continent (London: printed for Robert Leybourn, 1651), 77.

67 Henry Whistler, quoted in Dunn, Sugar and Slaves, 77; Handler, 'Father Antoine Biet's Visit', 66-7.

68 Ligon, $A$ True and Exact History, 53.

69 Vokins, God's Mighty Power Magnified, 43.

70 Wiseman, 'Read Within', 164.

71 Knott, 'Joseph Besse and the Quaker Culture of Suffering', 131.

72 Wiseman, 'Read Within', 166-7.

73 Curwen, A Relation of the Labour, 18; original emphasis.

74 Ibid., 6.

75 On the Barbadian economy, and its transition from one based on tobacco to one based on sugar, see Dunn, Sugar and Slaves; Gragg, Englishmen Transplanted; Schwartz, Tropical Babylons; Menard, Sweet Negotiations.

76 Karl Marx, Capital: A Critique of Political Economy, vol. 1, ed. Frederick Engels, trans. Samuel Moore and Edward Aveling (Moscow: Progress Publishers, 1954), 201.

77 Ibid., 209.

78 Ibid.

79 I am grateful to Alison Findlay for discussions on this point.

80 Puckrein, Little England, 81. The Church of England later ruled that conversion did not in itself emancipate slaves, rejecting the theological view that one Christian could not enslave another, and argued for the Christianisation of slaves; and in 1691 the Barbados General Assembly approved the baptism of blacks; 
Puckrein, Little England, 167. See too Amussen, Caribbean Exchanges, 114-16, 141-2, and Gragg, The Quaker Community, 121-41. See too note 87 below.

81 Kenneth L. Carroll, 'George Fox and Slavery', Quaker History, 86:2 (1997), 16-25 (21).

82 George Fox, 'To Friends beyond Sea, that have Blacks and Indian Slaves', in Selections from the Epistles, Ec. of George Fox, ed. Samuel Tuke (London: W. Alexander and Son, 1825), 94-5 (95).

83 The Presbyterian minister Richard Baxter also made a case for the Christianising of slaves on the basis of their common humanity in his A Christian Directory (1673). For a discussion of this and other contemporary dissenting critiques of slavery, see Amussen, Caribbean Exchanges, 179-84.

84 Ingle, First Among Friends, 235.

85 Dunn, Sugar and Slaves, 105.

86 Besse, Sufferings, II.308.

87 On the development of the Quaker position regarding slavery, see Herbert Aptheker, 'The Quakers and Negro Slavery', Journal of Negro History, 25:3 (1940), 331-62; Thomas E. Drake, Quakers and Slavery in America (New Haven: Yale University Press, 1950); J. William Frost (ed.), The Quaker Origins of Antislavery (Norwood, PA: Norwood Editions, 1980); J. William Frost, 'George Fox's Ambiguous Anti-Slavery Legacy', in Michael Mullett (ed.), New Light on George Fox 1624-1691 (York: The Ebor Press, 1994), 69-88; Kenneth L. Carroll, 'George Fox and America', in Mullett (ed.) New Light on George Fox, 59-68; Carroll, 'George Fox and Slavery'; Gragg, The Quaker Community, 121-41.

88 Fox, To the Ministers, Teachers, and Priests, 69; original emphasis.

89 Ibid., 5. The Church of England clergyman and missionary Morgan Godwyn cites (in paraphrase) these words of Fox's in his own text, in which he makes the case for the Christianising of slaves in Barbados and America. Despite condemning Fox's argument as a 'Quakers Harangue', he can only answer it with Ovid's words: 'Pudet haec opprobria nobis / Et dici potuisse, et non potuisse refelli [I am ashamed to hear this objected by strangers, and know not how to answer it]': Morgan Godwyn, The Negro's \& Indians Advocate, Suing for their Admission into the Church (London: printed for the author, by J. D., 1680), 4-6. He also includes the words on the title page of his A Supplement to the Negro's \& Indians Advocate (London: printed by J. D., 1681). Godwyn urged planters to care for the spiritual welfare of their slaves, but saw no difficulty with Christians owning Christian slaves.

90 Pinder, A Loving Invitation, 7.

91 Ibid., 9.

92 William Edmundson, 'To the Governour and Council, and all in Authority, in this Island of Barbadoes' (1675), in Besse, Sufferings, II.306-8 (307).

93 Edmundson, Journal, 77.

94 Ibid., 78.

95 I am grateful to Rex Ambler for drawing this text to my attention.

96 George Fox, Gospel Family Order, Being a Short Discourse concerning the Ordering of Families, Both of Whites, Blacks and Indians (s.1.: s.n., 1676), 19. 
97 Ibid., 4.

98 Ibid., 9, 12.

99 Ibid., 13, 14.

100 Ibid., 16; original emphasis.

101 For Fox and his followers, a state of human perfectibility, or prelapsarian perfection, was possible in this life through the power of the indwelling Christ within each believer. Turning to the inward light would make good the losses of the fall: as Bailey put it, Friends' belief that the celestial body of Christ dwelt within them meant they 'had been restored to the pre-Fall paradisiacal state. In them the restoration of the image of God was absolute' (Richard G. Bailey, New Light on George Fox and Early Quakerism: The Making and Unmaking of a God (San Francisco: Mellen Research University Press, 1992), 44). This 'fusion of flesh and spirit' is at the heart of 'Friends' ideology of immanence - salvation embodied in the "celestially fleshed Christ" of one another'; Tarter, 'Quaking in the Light', 148. For a fuller discussion of Quaker ideas of perfectibility, see Chapter 1, 20-1, and 162n.45, above.

102 William Edmundson, 'For Friends in Maryland, Virginia and Other Parts of America', in Frost, The Quaker Origins of Anti-Slavery, 66-7 (66, 67).

103 Frost, 'George Fox's Ambiguous Anti-Slavery Legacy', 70.

\section{Conclusion}

1 Geoffrey F. Nuttall, The Holy Spirit in Puritan Faith and Experience (Oxford: Basil Blackwell, 1947), 150.

2 Thomas Edwards, Gangraena: or A catalogue and discovery of many of the errours, heresies, blasphemies and pernicious practices of the sectaries of this time (London: printed for Ralph Smith, 1646); John Milton, Areopagitica, in Prose Writings (London: J. M. Dent, 1958).

3 Rosemary Moore suggests that the public dispute between Edward Burrough and John Bunyan in Bedford in May 1656, which was then followed up by four books (including Bunyan's first published work) over the next few months, 'dealt most fully with the Quaker understanding of Christ' (Rosemary Moore, The Light in Their Consciences: The Early Quakers in Britain 1646-1666 (University Park, PA: Pennsylvania State University Press, 2000), 105). On this dispute, see too William C. Braithwaite, The Beginnings of Quakerism (Cambridge: Cambridge University Press, 2nd ed., 1955), 286-8, and T. L. Underwood, Primitivism, Radicalism, and the Lamb's War: The Baptist-Quaker Conflict in Seventeenth-Century England (Oxford: Oxford University Press, 1997), 51-4. George Fox also responded to Bunyan's two anti-Quaker texts in The Great Mistery of the Great Whore Unfolded (1659).

4 Norman Penney (ed.), The First Publishers of Truth: Being Early Records (Now First Printed) of the Introduction of Quakerism into the Counties of England and Wales. Supplement to Journal of the Friends' Historical Society, 1-5 (London: Headley Brothers, 1907), 243.

5 See Rosemary Moore's bibliography of anti-Quaker publications 1653-66 at www.qhpress.org/cgi-bin/rmoore/antiq.html (accessed 28 January 2010). 
6 William Robinson and Marmaduke Stephenson were hanged in 1659, Mary Dyer in 1660, and William Leddra in 1661; as Quakers they had all been banished from Boston on pain of death if they returned; all returned. See Braithwaite, Beginnings of Quakerism, 404; Rufus M. Jones, The Quakers in the American Colonies (New York: W. W. Norton, 1966), 76-89.

7 The 'Meeting for Sufferings' remains an important part of Quakerism today, as 'the standing representative body entrusted with the care of the business of the Britain Yearly Meeting through the year. This first met in 1675. Its original purposes included obtaining redress from both Parliament in cases of individual suffering and seeking to liberalise the laws relating to religious toleration'; www.quaker.org. uk/meeting-sufferings (accessed 5 November 2009). On the origins of 'Quaker Sufferings' literature, see Rosemary Moore, 'Reactions to Persecution in Primitive Quakerism', Journal of the Friends' Historical Society, 57:2 (1995), 123-31 (124-6); see too John R. Knott, 'Joseph Besse and the Quaker Culture of Suffering', in Thomas N. Corns and David Loewenstein (eds), The Emergence of Quaker Writing: Dissenting Literature in Seventeenth-Century England (London: Frank Cass, 1995), 126-41.

8 George Fox, The Journal, ed. Nigel Smith (London: Penguin, 1998), 13, 240.

9 George Fox, The Journal of George Fox, ed. John L. Nickalls (Cambridge: Cambridge University Press, 1952), 228.

10 On the 'hard, slow, inner conflict' of convincement, see Hugh Barbour, The Quakers in Puritan England (New Haven: Yale University Press, 1964), 94-126.

11 Joseph Besse, A Collection of the Sufferings of the People called Quakers, 2 vols (London: printed and sold by Luke Hinde, 1753), I.519.

12 For a rich and fascinating study of Puritan (principally Calvinist) allegory and metaphor, see Thomas Luxon, Literal Figures: Puritan Allegory and the Reformation Crisis in Representation (Chicago and London: The University of Chicago Press, 1995).

13 Michel de Certeau, The Practice of Everyday Life, trans. Steven Rendell (Berkeley: University of California Press, 1984), 130.

14 Richard Farnworth, The Pure Language of the Spirit of Truth, Set forth for the confounding false Languages, acted out of Pride, Ambition and Deceit. Or, Thee and Thou, In its place, is the proper Language to any single person whatsoever (London: printed for Giles Calvert, 1655), 6; Fox, Journal, ed. Nickalls, 198.

15 Fox, Journal, ed. Smith, 176. 